\title{
Guernsey-Crown Dependency of the United Kingdom: Assessment of the Supervision and Regulation of the Financial Sector Volume I-Review of Financial Sector Regulation and Supervision
}

This review of financial sector regulation and supervision in Guernsey in the context of the offshore financial center assessment program contains technical advice and recommendations given by the staff team of the International Monetary Fund in response to the authorities of Guernsey's request for technical assistance. It is based on the information available at the time it was completed in October 2003. The staff's detailed assessment of the observance of standards and codes can be found in Volume II. The views expressed in these documents are those of the staff team and do not necessarily reflect the views of the government of Guernsey or the Executive Board of the IMF.

The policy of publication of staff reports and other documents by the IMF allows for the deletion of market-sensitive information.

To assist the IMF in evaluating the publication policy, reader comments are invited and may be sent by e-mail to publicationpolicy@imf.org.

Copies of this report are available to the public from

International Monetary Fund $\bullet$ Publication Services

700 19th Street, N.W. • Washington, D.C. 20431

Telephone: (202) $6237430 \bullet$ Telefax: (202) 6237201

E-mail: publications@imf.org •Internet: http://www.imf.org

Price: $\$ 15.00$ a copy

\section{International Monetary Fund Washington, D.C.}


ASSESSMENT OF THE SUPERVISION AND REGULATION OF THE FinANCIAL SECTOR



\title{
Volume I: Review of Financial Sector Regulation and Supervision
}

\section{Guernsey}

\author{
October 2003
}


"The contents of this report constitute technical advice and recommendations given by the staff of the International Monetary Fund (IMF) to the authorities of Guernsey in response to their request for technical assistance. With the written authorization of the recipient country's authorities, this report (in whole or in part) or summaries thereof may be disclosed to IMF Executive Directors and their staff, and to technical assistance providers and donors outside the IMF. Disclosure of this report (in whole or in part) or summaries thereof to parties outside the IMF other than technical assistance providers and donors shall require the written authorization of the recipient country's authorities and the IMF's Monetary and Financial Systems Department.” 


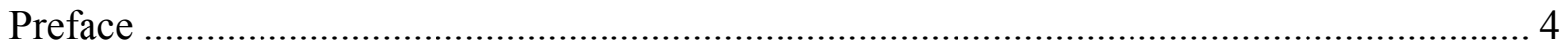

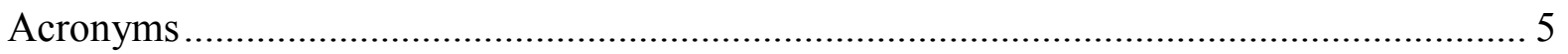

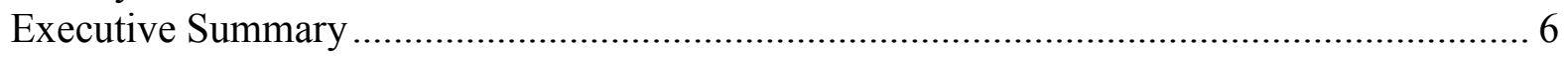

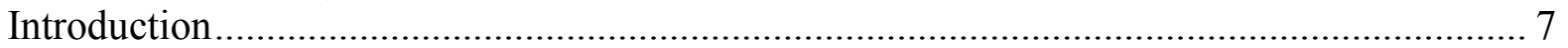

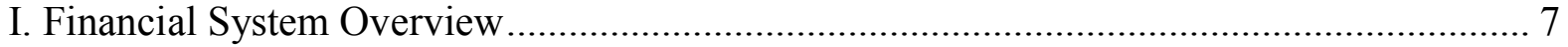

A. Background …............................................................................................ 7

B. Financial Institutions and Markets ...................................................................... 8

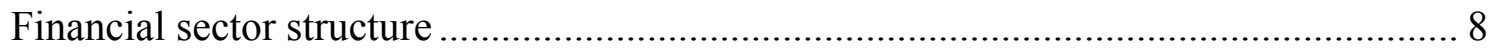

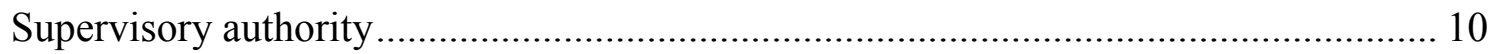

C. Regulatory Framework Oversight_-Market Integrity Arrangements ........................ 11

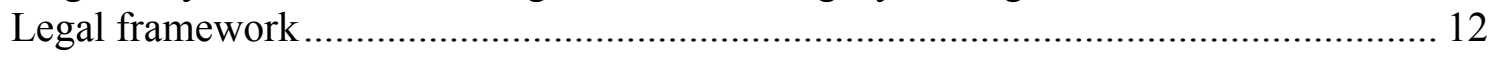

II. Strengths and Vulnerabilities in the Financial Regulatory and Supervisory Arrangements

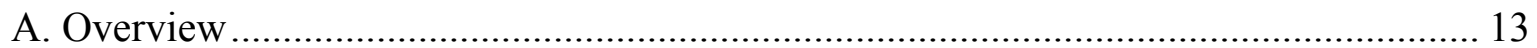



B. Actions to Strengthen the Observance of Standards and Codes ............................... 16



III. Observance of Financial System Standards and Codes: Summary Assessments ........... 20

A. Basel Core Principles for Effective Banking Supervision ........................................ 20

Institutional setting and market structure ............................................................. 20

General preconditions for effective banking supervision ....................................... 21

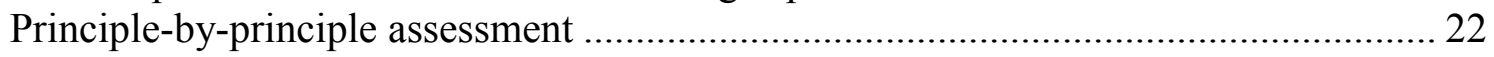

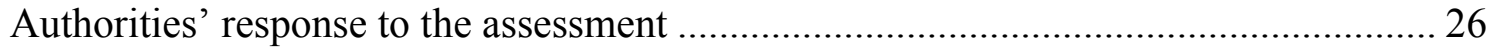

B. FATF Recommendations for Anti-Money Laundering and Combating the Financing of

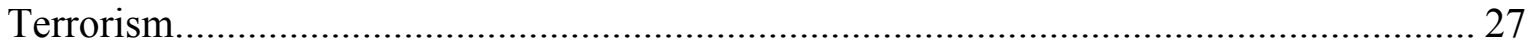

Information and methodology used for the assessment ........................................... 28

Preventive measures for financial institutions ..................................................... 30

Summary assessment against the FATF recommendations.................................... 32



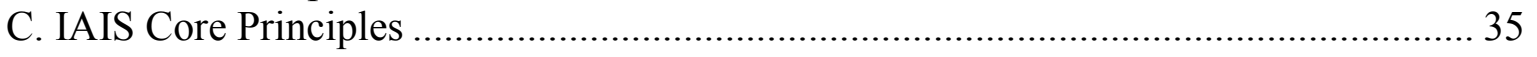

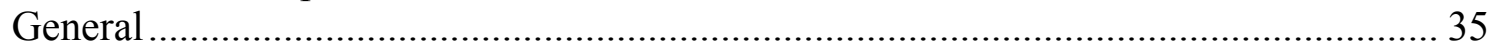

Institutional and macroprudential setting_-overview............................................. 35

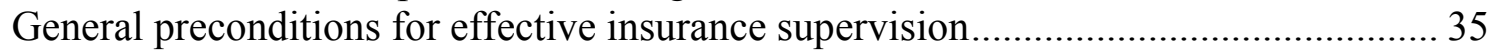

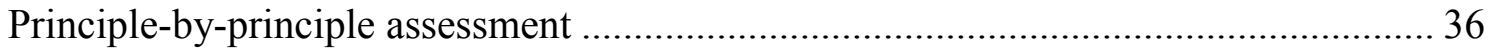

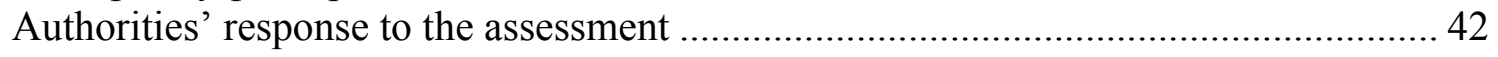

D. IOSCO Objectives and Principles of Securities Regulation ...................................... 42



Information and methodology used for assessment ................................................. 43

General preconditions for effective securities regulation .......................................... 44

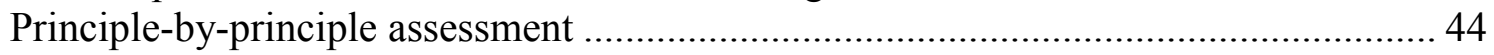

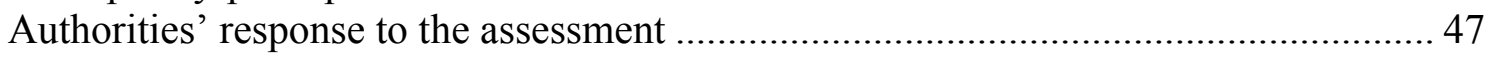


IV. Plan by the Bailiwick of Guernsey for Addressing the Recommended Action Plans of the International Monetary Fund to Enhance Compliance with International Regulatory

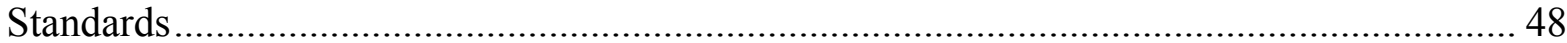

A. Authorities' Response to the IMF's Recommended Action Plans ............................ 49

Text Tables

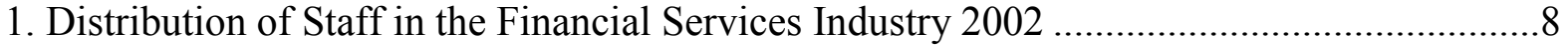

2. Assets and Liabilities of Licensed Banks at Year-End ...................................................22

3. Recommended Actions to Improve Compliance with the Basel Core Principles ..............26

4. Recommended Action Plan to Improve Compliance with the FATF Recommendations 33

6. Recommended Action Plan for Observance of IAIS Insurance Core Principles ...............41

7. Recommended Plan of Actions to Improve Observance of the IOSCO Objectives and Principles of Securities Regulation ........................................................................46 


\section{Preface}

In July 2000, the Executive Board approved a program of assessments on the basis of the paper "Offshore Financial Centers-The Role of the IMF," published in July 2000. In this context, the government and the Guernsey Financial Services Commission (GFSC) invited the IMF to carry out an assessment of the extent to which the regulatory and supervisory arrangements for the financial sector complied with certain internationally accepted standards and measures of good practice (a Module 2 assessment as described in the above-mentioned paper).

The assessments were carried out during a mission from November 13-26, 2002. The mission was led by Mr. R. Barry Johnston (Monetary and Financial Systems Department (MFD) ) and comprised Messrs. Neville Grant (Consultant MFD, Deputy Mission Chief); Ian Carrington (MFD); Ross Delston (Consultant, Legal Department); John Farrell; Helmut Müller; Jack Heyes; and Marcel Maes (all Consultants, MFD); and Mrs. Sandra Solares (Administrative Assistant, MFD). Detective Chief Superintendent Felix McKenna was the independent anti-money laundering expert for the AML/CFT assessment.

The mission undertook a review of all relevant current legislation and practices, and held discussions with the regulatory authorities, certain government officials, and a broad cross-section of the private-sector practitioners. The mission is most grateful for the excellent cooperation, openness, and hospitality of all the agencies consulted during its visit, and especially to the GFSC for the excellent organization of the visit. 


\section{ACRONYMS}

AML

AML/CFT

CISX

CP

DT Law

EC

EU

fiduciaries

FI

FIS

FT

GFSC

IAIS

IOSCO

KYC

LEG

MFD

MOU

MSB

OFC

OGBS

PCC

POI

ROSCs

SRO

STR

States Assembly anti-money laundering

anti-money laundering and combating the financing of terrorism Channel Islands Stock Exchange

Core Principle

The Drug Trafficking (Bailiwick of Guernsey) Law, 2000

European Community

European Union

company and trust service providers

financial institution

Financial Intelligence Service

financing of terrorism

Guernsey Financial Services Commission

International Association of Insurance Supervisors

International Organization of Securities Commissions

know your customer

Legal Department

Monetary and Financial Systems Department ${ }^{1}$

Memorandum of Understanding

Money Service Business

Offshore Financial Sector Assessment Program

Offshore Group of Banking Supervisors

protected cell company

The Protection of Investors (Bailiwick of Guernsey) Law, 1987

Reports on Standards and Codes

self-regulatory organization

suspicious transactions report

Guernsey Parliament

\footnotetext{
${ }^{1}$ The IMF's Monetary and Exchange Affairs Department (MAE) was renamed the Monetary and Financial Systems Department (MFD) as of May 1, 2003. The new name has been used throughout the report.
} 


\section{EXECUTIVE SUMMARY}

The financial, regulatory, and supervisory system of the Bailiwick of Guernsey complies well with the assessed international standards. The authorities are to be commended for the attention they have given to upgrading the financial regulatory and supervisory system to meet international standards in banking, insurance, securities, anti-money laundering (AML) and combating the financing of terrorism (AML/CFT), and best practices for company and trust service providers (fiduciaries). The mission noted in particular:

- the comprehensive regulatory framework;

- the proactive approach of the regulators to achieve high standards in the financial services sector; and

- $\quad$ an off- and on-site supervisory process that has been addressing the key types of reputational risk to the Bailiwick.

The jurisdiction has been assessed to have a high level of compliance with the four standards. The legal framework for company and trust service providers is fully consistent with the Offshore Group of Banking Supervisors (OGBS) Statement of Best Practice.

The assessments identify the following areas where consideration should be given to further strengthen the legal, regulatory, and supervisory arrangements:

- the functions and independence of the GFSC;

- $\quad$ resources devoted by the GFSC to bank supervision;

- $\quad$ certain supervisory and regulatory arrangements in banking and securities; and

- $\quad$ the AML/CFT legal framework, the coverage of guidance notes, and communication of some policies.

The authorities are, therefore, encouraged to take actions in the following areas: ${ }^{2}$

- $\quad$ enhance the independence of the regulator;

- $\quad$ the GFSC Law should establish safety, soundness, and integrity of the financial system as the objectives of the GFSC and eliminate "development" as one of the GFSC functions;

- $\quad$ address the resource deficit identified in the GFSC's Banking Division;

- $\quad$ enhance certain GFSC powers and procedures; and

\footnotetext{
${ }^{2}$ The "Authorities response-overview" appears at page 17.
} 
- $\quad$ enhance the legal framework on AML/CFT, broaden the coverage of the guidance notes in certain areas, and reinforce the communication of certain AML/CFT policies.

\section{INTRODUCTION}

This report provides the findings of the Module 2 assessment of the Bailiwick of Guernsey. The report is organized in two volumes. Volume I provides an overview and the summary findings, and the Reports on the Observance of Standards and Codes (ROSCs). Volume II provides the detailed assessments of the Basel Core Principles for Effective Banking Supervision; the Insurance Core Principles of the IAIS; the Objectives and Principles of Securities Regulation of the IOSCO; and the FATF 40+8 Recommendations, as well as a review against the OGBS Statement of Best Practice for Trust and Company Service Providers.

Volume I is presented in three chapters. Chapter I provides an overview of the financial system, and the regulatory and supervisory framework. Chapter II summarizes the findings on the strengths and vulnerabilities in the financial system. Chapter III provides the ROSCs for the assessments of the Basel Core Principles, IAIS, IOSCO, and the FATF Recommendations. The full detailed assessments for each of the standards are provided in Volume II.

The Bailiwick of Guernsey comprises the principal Islands of Guernsey (population 62,000), Alderney (population 2,000), and Sark (population 600), together with other smaller islands. The Bailiwick of Guernsey is referred to as Guernsey or 'the Bailiwick' in this report. The laws and regulations of Guernsey also apply to Alderney and Sark, except in the case of companies and trusts.

\section{FinANCial SyStem OVERVIEW}

\section{A. Background}

1. The financial services sector plays a dominant role in the economy of Guernsey. Measured by the number of persons employed, the relative importance of financial services in the Guernsey economy has increased substantially in the last 10 years against the background of supportive national policies, especially a favorable tax regime; a well-developed legal and institutional infrastructure; close proximity to Europe and the London international financial center; and a regulatory approach that considers the need to meet international financial regulatory standards. The financial industry accounted for an estimated 65 percent of Guernsey's export economy in 2001. 


\section{B. Financial Institutions and Markets}

\section{Financial sector structure}

2. Guernsey attracts a diverse range of financial businesses, including banking, insurance, investment, trust, and company business (Table 1).

Table 1. Distribution of Staff in the Financial Services Industry 2002

\begin{tabular}{lcc}
\hline & Number & Percent \\
\hline Banking & 2,750 & 41.6 \\
Insurance and investment business & 1,304 & 19.7 \\
Trust business & 2,556 & 38.7 \\
& & \\
Total & 6,610 & 100.0 \\
\hline
\end{tabular}

\section{Banking}

3. There are 69 banks licensed to take deposits under the Banking Supervision (Bailiwick of Guernsey) Law, 1994. These banks are subsidiaries or branches and come from Europe, Asia, the Middle East, North America, and South Africa. Total deposits stood at $£ 71.8$ billion at the end of September 2002, the largest source being fiduciary deposits.

4. Licensed banks carry out private banking services for nonresidents, corporate banking, deposit gathering for funding parent operations, and retail banking for the local population. Some banks also carry out custody work for mutual funds and others provide banking services to the captive insurance sector.

5. The majority of bank assets are placed in the money market with London being the primary destination. Bank placements to fund United Kingdom parent businesses are important. The European Union (EU) and Switzerland are also significant destinations for bank assets as a result of group placements, as well as the United States, primarily, for investments in U.S. Government papers.

6. Banking in Guernsey is going through a transition and the rate of change parallels what is occurring internationally. The number of banks is decreasing and mergers are expected to continue; there is ongoing pressure within groups to streamline operations and reduce duplication. ${ }^{3}$

\footnotetext{
${ }^{3}$ Examples of the type of rationalization and consolidation that have occurred within the jurisdiction are that Lloyds have centered certain operations in Jersey and, as part of their rationalization program, stand-alone entities will become branches. Barclays has centered
} 


\section{Insurance}

7. Guernsey is one of the largest captive insurance markets in the world. The number of captive insurance companies and protected cell companies totals 383 , the majority of which are managed by 30 captive insurance management companies licensed in the jurisdiction. Typically, the captives are subsidiaries of major industrial organizations set up as dedicated insurance vehicles to help those organizations manage their insurance and risk-management programs. Funds under management were $£ 9.3$ billion and annual premium income was $£ 2.07$ billion in 2002 .

8. There are 26 authorized international life assurance companies incorporated and managed in the jurisdiction. These include a wide variety of companies with diverse size and spread of business. The companies are subsidiaries of financial institutions (FIs) from France, Italy, Luxembourg, South Africa, the United Kingdom, and the countries of Scandinavia. These companies manage some $£ 2.86$ billion of gross assets. Annual income for 2002 was $£ 0.83$ billion.

9. Protected cell company (PCC) is a new form of company vehicle designed to make the advantages of captive insurance available to smaller companies by reducing costs. It also provides cost reduction benefits for investment funds. Guernsey was the first jurisdiction to introduce by law the concept of PCCs. It is used, for instance, by large industrial groups for their different subsidiaries. At the end of 2002, there were 50 licensed PCCs with 214 cells.

\section{Securities}

10. There were 208 collective investment schemes and 322 closed-ended collective investment funds established with licensed fund managers and third-party fund administrators at end-September 2002, of which the total value was $£ 31.9$ billion.

11. The Channel Islands Stock Exchange (CISX) commenced operations in 1998. It offers trading and listing facilities for investment funds, debt instruments, and shares in companies. The number of securities admitted to the CISX as at October 2002 was 280, and the market capitalization was $\$ 17$ billion. The exchange concentrates on open- and closed-end investment funds and special debt instruments. The market is screen-based with no trading floor. The CISX does not provide clearance and settlement facilities.

certain operations on the Isle of Man and, as part of their rationalization program, stand-alone entities will become branches; and HSBC is in the process of consolidation and the bank has outsourced a significant amount of the back-office operations to India. 
As at June 30, 2002, there are 428 companies licensed to conduct controlled investment business, including 267 fund managers and administrators; 108 fiduciaries, banks and nonGuernsey firms conducting investment business; 15 fund custodians; 21 intermediaries/ independent financial advisers; 13 investment advisers; 3 stockbrokers; and the CISX. The number of companies registered in Guernsey is 15,910 and 484 are registered in Alderney. No companies are incorporated in Sark, as it has no company law.

\section{Companies and trusts (fiduciaries)}

12. There are 189 licensed providers of trust and corporate services. Of this figure, 141 are companies or partnerships holding full fiduciary licenses (authorizing the holder to undertake the full range of fiduciary activities) and 48 are individuals holding personal fiduciary licenses. A personal fiduciary license is a restricted category of license authorizing the holder to act as a company director or as a trustee (but not as a sole trustee). There are still fiduciaries operating under transitional provisions.

\section{Supervisory authority}

13. The GFSC was established as a statutory body under the Financial Services Commission (Bailiwick of Guernsey) Law 1987 as a unitary regulator responsible for the regulation of financial services business. The Advisory and Finance Committee of the States Assembly is mandated to oversee the financial services sector, and to monitor and act as the channel of communication with the GFSC. The GFSC is required to make an annual report to the Advisory and Finance Committee that is laid before parliament. After consulting the GFSC, the committee may give written guidance and direction of a general character concerning the policies to be followed.

14. At the time of the assessment, the GFSC's affairs were directed by a board of five members, of whom the chairman was the president of the Advisory and Finance Committee. The president of the Advisory and Finance Committee was required to be chairman of the GFSC. The 2002 amendment to the GFSC Law, the final provisions of which came into effect in February 2003, provides that it is no longer necessary for the chairman to hold political office. The four other members are selected by parliament for terms of three years and can be reelected. The president of the Advisory and Finance Committee has since stepped down as chairman and has been replaced by a nonpolitician. The GFSC is funded by fees levied on the regulated institutions and, since November 1, 2002, sets its fees after consultation with the Advisory and Finance Committee. ${ }^{4}$

\footnotetext{
${ }^{4}$ Prior to November 1, 2002, the fees were set by the Advisory and Finance Committee of Guernsey in consultation with the GFSC. The November 1 change is intended to provide the GFSC with greater independence in setting its fees.
} 
15. The general functions of the GFSC include:

(a) taking such steps as it considers necessary or expedient for the development and effective supervision of finance business in the Bailiwick;

(b) providing, when requested, reports, advice, and assistance to the responsible committee of the States Assembly on any matter connected with finance business;

(c) preparing and submitting recommendations for the statutory regulation of finance business and the revision of legislation about companies and other forms of business undertakings to the responsible committees; and

(d) the countering of financial crime and of the financing of terrorism (FT).

16. The GFSC states in its Annual Report that "The Commission's primary objective is to regulate the Bailiwick's finance sector to international standards and, by doing so, to protect depositors, investors, policy holders, other customers, and the public."

17. The GFSC has a staff of 75 (including 5 consultants) and is divided into four regulatory and two support Divisions that report to the Director General, who is the chief executive. Supervision of the different sectors, (banking, insurance, investment, and fiduciary business) is exercised mainly by the four respective regulatory Divisions. Staff numbers have increased to 88 at the end of July 2003.

\section{Regulatory Framework Oversight-Market Integrity Arrangements}

18. Guernsey is a Crown Dependency but largely self-governing. The United Kingdom has ultimate responsibility for the jurisdiction's defense and international relations, but within clearly set conventions. The States Assembly delegates administration to committees with specific functions. The Advisory and Finance Committee is mandated to oversee the financial services sector. The Bailiwick has its own laws and legal system, and its own system of regulation and law enforcement. Laws are contained either in legislation enacted by or under the authority of the States Assembly, or in Guernsey customary law.

19. Guernsey is neither a separate member state nor an associate member of the EU. On the United Kingdom's entry into the common market, a protocol to the Treaty of Accession was negotiated. The protocol sets out the very limited extent to which European measures apply within the Bailiwick. By virtue of the protocol, Guernsey complies with the European measures on trade, industrial, and agricultural products. Under Protocol 3, the jurisdiction is part of the customs territory of the European Community (EC). The common customs tariff, levies, and other measures relating to trade apply and there is free movement of goods in trade between Guernsey and the EC; however, no other EU rules apply. 


\section{Legal framework}

20. Guernsey has a comprehensive system of financial sector regulation:

- The responsibilities of the GFSC are set out in the Financial Services Commission (Bailiwick of Guernsey) Law, 1987, and amendments (the GFSC Law). The GFSC Law confers certain general powers that provide that the GFSC may do anything that appears to it to be conducive to the carrying out of its functions.

- The Banking Supervision (Bailiwick of Guernsey) Law, 1994, as amended, provides for the regulation of deposit-taking business. It gives the GFSC the ability to set out conditions for issuing licenses. The Law restricts the acceptance of deposits to licensed institutions and provides for the regulation and supervision of such institutions. It also gives the GFSC the ability to impose conditions on licensees, give directions to institutions, impose penalties for breach of legislation, and revoke licenses.

- The Insurance Business (Bailiwick of Guernsey) Law, 2002, provides for the regulation and supervision of insurance companies. It restricts the carrying on of business to licensed institutions and sets out the conditions for licensing. It also provides for the suspension, revocation, and surrender of licenses and gives the GFSC the authority to issue directions to insurers. There is a policyholder-protection-scheme in place and the Act includes provisions for the establishment of a Compensation Scheme.

- The Insurance Managers and Insurance Intermediaries (Bailiwick of Guernsey) Law, 2002, complements the Insurance Business Law. It permits the GFSC to restrict who can act as an insurance manager or intermediary, and provides for their licensing and supervision. It also provides for the suspension, revocation, and surrender of licenses.

- The Protection of Investors (Bailiwick of Guernsey) Law, 1987 (the POI Law), sets out the responsibilities and powers of the GFSC in connection with investment business. The Law requires persons who carry out activities that include administration, advising, custody, management, dealing, promotion, registration, and subscription in respect of certain specified investments to be licensed.

- The Companies (Guernsey) Law, 1994 and the Companies (Alderney) Law, 1994, provide for the incorporation of companies. The Laws provide for several types of companies. Each company must have its registered office in Guernsey where the register of shareholders and directors must be kept. Guernsey introduced PCC legislation. There is no company law in Sark and, therefore, companies cannot be incorporated in that jurisdiction. The Trusts (Guernsey) Law, 1989, and subsequent amendments provide for the setting up of trusts. 
- $\quad$ Fiduciaries are licensed, regulated, and supervised under the Regulation of Fiduciaries, Administration Businesses and Company Directors, etc. (Bailiwick of Guernsey) Law, 2000. All those engaged in the provision of regulated fiduciary activities in Guernsey must be licensed. Guernsey is one of the first jurisdictions to apply a comprehensive regulatory regime to persons providing company and trust services.

- The AML regime is supported by a number of statutes including the Criminal Justice (Fraud Investigation) (Bailiwick of Guernsey) Law, 1991; the Disclosure of Information Laws, Guernsey (1995), Alderney (1998) and Sark (2001); the Criminal Justice (Proceeds of Crime) (Bailiwick of Guernsey) Law, 1999; the Drug Trafficking (Bailiwick of Guernsey) Law 2000; and the Terrorism and Crime (Bailiwick of Guernsey) Law, 2002.

\section{STRENGTHS AND VULNERABILITIES IN THE FinANCIAL REgUlatory AND SUPERVISORY ARRANGEMENTS}

\section{A. Overview}

21. The detailed assessments of compliance show that the financial regulatory system of Guernsey complies well with the international standards. These assessments were conducted against the Basel Core Principles for Effective Banking Supervision; the Insurance Core Principles of the IAIS; the Objectives and Principles of Securities Regulation of the IOSCO; and FATF 40+8 Recommendations. The jurisdiction was also reviewed against the OGBS Statement of Best Practice for Company and Trust Service Providers.

22. The GFSC is a well-established and well-respected supervisory agency with an experienced staff. The GFSC has a good range of regulatory and enforcement powers, and the supervisory process is, in general, effective. The legal framework for company and trust service providers is fully consistent with the OGBS Statement of Best Practice.

23. The assessments identified two issues that could impair the operational independence of the GFSC:

(1) The provisions in Section 7 of the GFSC Law, authorizes the Advisory and Finance Committee to give to the GFSC written guidance and direction of general character, concerning the policies to be followed by the GFSC in relation to development and supervision of the finance business in the Bailiwick, and the manner in which any functions of the GFSC are to be carried out. 
(2) The GFSC Law provides in Section 2 that, "The general functions of the Commission are to take such steps as it considers necessary or expedient for the development and effective supervision of finance business in the Bailiwick." ${ }^{5}$ Under the GFSC Law, "development" and "effective supervision" are functions of the GFSC, and the Law does not provide a clear way to resolve potential conflicts between these objectives.

24. The mission acknowledges that the committee's power to give guidance and direction has not interfered to date with the GFSC's capacity to carry out its functions, and that development and effective supervision can be complementary objectives. It is noted that the Advisory and Finance Committee has never unilaterally provided guidance or direction to the GFSC. However, a regulator is called on from time to time to make difficult decisions affecting the finance sector or its individual members. The current Law has the potential to compromise the judgment and, therefore, the independence of the supervisors should be redrafted as discussed below.

\section{Sectoral assessments}

25. In addition to the above general observation, the following provides a brief summary of the sectoral assessments. More details are provided in the ROSCs in Chapter III and the detailed assessments in Volume II.

\section{Basel Core Principles}

26. Guernsey has a high level of compliance with the Basel Core Principles. The assessment noted two areas where the legal and supervisory framework could be strengthened. The first concern relates to the GFSC's functions and its independence (as noted above). The second concern is the current resource deficit in the Banking Division. Unless the Banking Division is adequately resourced, the progress made to date will not be sustainable, nor will the Division be able to address the mandate envisioned going forward in an effective manner.

\footnotetext{
5 The Law elaborates in Section 2A that "development includes, without limitation, the establishment and ongoing support of bodies and organizations the functions of which include or are important or relevant to: (i) the development of finance business in the Bailiwick and of that sector of the economy, which carries on finance business with the general function to develop the financial business of the islands; (ii) the improvement of the infrastructure of or serving that sector of the Bailiwick economy, which carries on finance business; (iii) the protection of the public; and (iv) the protection and enhancement of the Bailiwick as a financial center."
} 


\section{IAIS Core Principles}

27. The mission found a high level of compliance with the IAIS Core Principles. Some concern was expressed about the functions and independence of the regulator. The formal insurance framework is very new and the legislation has recently been amended to reach compliance with international standards. The mission concurs with the proposed increase in staff to be assigned to insurance supervision.

\section{IOSCO Principles}

\section{Guernsey has achieved a high standard of compliance with the IOSCO}

Principles. Issues raised by the assessment related to the independence of the regulator; limitations on the GFSC's powers of on-site inspection; its statutory power to obtain information from any person for the purpose of communicating that information to a foreign regulator; and the absence of complete procedures for dealing with the failure of a market participant. These observations relate to deficiencies in the legal framework for investment activity that are covered in the legal frameworks for banking and insurance.

\section{FATF 40+8 Recommendations}

29. The AML/CFT regime is generally satisfactory, with a developed legal framework and awareness among the industry. There is a high level of compliance with the FATF Recommendations.

- Guernsey has a developed legal and institutional framework for AML/CFT, particularly, with respect to confiscation of the proceeds of criminal conduct, exchange of information, and international cooperation. The broad regulation of the financial sector is another strength.

- The general framework for AML/CFT has been well implemented. The GFSC has devoted an appropriate level of resources to this issue. Detailed guidance notes have been developed and the GFSC has established a program of on- and off-site surveillance of financial service businesses to assess compliance with required standards. There is a strong relationship among the principal institutions involved. FIs revealed a high level of awareness and, in general, the existence of appropriate $\mathrm{AML} / \mathrm{CFT}$ policies and procedures.

\section{Company and trust service providers}

30. The GFSC's regulatory and supervisory framework for fiduciaries is consistent with the practices set out in the OGBS "Statement of Best Practice" for trust and company service providers.

31. The GFSC appears to have dealt well with the application process for fiduciaries. There are still a small number of fiduciaries operating under the "transitional provisions" of the Law. These companies and individuals are fully covered by the 
supervisory and enforcement provisions of the legislation, but some have not yet been licensed because the GFSC is not fully satisfied that they meet all of the licensing criteria. The GFSC believes that it is making every effort to complete the process as effectively and efficiently as possible, consistent with the need for each decision to be based on a detailed consideration of each individual application that must involve proper respect for due process. The GFSC has set up an appeals tribunal to further expedite the licensing during the transitional process. The mission recommends the setting of a cut-off date for completion of the licensing process to avoid inordinate delays.

\section{B. Actions to Strengthen the Observance of Standards and Codes}

32. The authorities in Guernsey are well aware that, to maintain the Bailiwick's position as a well-regulated jurisdiction, the islands will need to continue to update their supervisory and regulatory framework to reflect the changing international regulatory environment and international standards. This updating should include laws, regulations, and procedures, as well as the role and functions of the regulators. The following section outlines some key issues going forward.

\section{Functions and operational independence of the regulator}

33. As noted above, the operational independence of the GFSC is an issue in the assessments. This relates to: (1) the power of the Advisory and Finance Committee to provide guidance and direction to the GFSC; and (2) the GFSC's functional responsibility for the development of the financial system and the potential for this to conflict with its regulatory role. It is noted that the Advisory and Finance Committee has never unilaterally provided guidance or direction to the GFSC. However,

- $\quad$ in order to strengthen the independence of the GFSC, the mission recommends that the GFSC Law be amended to remove the power of the Advisory and Finance Committee to provide guidance and direction to the GFSC;

- $\quad$ the GFSC Law should establish safety, soundness, and integrity of the financial system as the objectives of the GFSC, and eliminate "development" as one of the GFSC functions. Further, there should be no provisions in the Law that could potentially compromise the above-stated objectives. This would provide a clear legal framework that would avoid potential conflicts in the functions of the GFSC. The attainment and sustainability of these objectives will enhance the reputation and contribute to the development of the financial system in Guernsey.

34. In addition, a number of more specific recommended actions are provided in the next section for each of the four assessed standards. 


\section{Authorities' response to the assessment}

\section{Overview}

35. The Guernsey authorities (the States of Guernsey Advisory and Finance Committee, the Attorney General's Chambers, the Guernsey Financial Services Commission and the Financial Intelligence Service) value and attach great significance to the IMF's Module 2 assessment of the Bailiwick of Guernsey, which endorsed the Bailiwick's high level of compliance with international regulatory standards in banking, insurance, securities, antimoney laundering and combating the financing of terrorism and best practice for company and trust service providers. The assessment was a welcome and positive experience.

36. The authorities also welcome the issues raised by the IMF, which will assist the Bailiwick to further enhance its implementation of established international standards.

37. Many of the IMF's recommendations are, or will be, satisfied by amendments to the framework already in progress at the time of the assessment. An action plan is appended to Volume I of the assessment report, which describes how the recommendations made by the IMF are being addressed.

38. The Bailiwick's standards were found by the IMF to be fully consistent with the Offshore Group of Banking Supervisors Statement of Best Practice for Trust and Company Service Providers. The authorities were, however, very concerned to be advised formally, soon after the review, that the IMF will not be assessing any other jurisdictions against the Statement. The authorities believe that the Statement represents an important international benchmark against which all jurisdictions which provide services to trusts and companies should be assessed. The absence of this benchmark means that the vast majority of jurisdictions which provide such services are not obliged to meet the standards in the Statement. This represents a missed opportunity for the IMF which could have made a substantial contribution to protecting the international financial system.

\section{Functions and independence}

39. The IMF's conclusion that the States of Guernsey Advisory and Finance Committee's ability under the Financial Services Commission (Bailiwick of Guernsey) Law, 1987 to give guidance and directions of a general character to the GFSC has not interfered with the GFSC's capacity to carry out its functions is noted. As stated by the IMF, the Committee has never unilaterally provided guidance or directions to the GFSC. As is also acknowledged, the law permits the Committee to give the GFSC guidance and directions only of general character. Both the Committee and the GFSC consider that this provision provides proper accountability by the GFSC to the Committee, which is the senior political body of Guernsey's parliament. The Committee and the GFSC consider that the ability to give guidance and directions of general character is in compliance with the international standard which applies to the independence of regulatory bodies. 
40. Currently, the GFSC has a responsibility under the Financial Services Commission (Bailiwick of Guernsey) Law, 1987 to develop and effectively supervise finance business in Guernsey. The IMF's recommendation that the GFSC should be provided with a statutory obligation for the safety, soundness and integrity of the financial system in place of its responsibility to develop the finance sector has been noted. The States of Guernsey Advisory and Finance Committee and the GFSC agree with the IMF's view that formalizing the GFSC's approach in this manner better expresses the GFSC's current and continuing objectives and will enhance the reputation and contribute to the continuing development of the financial system in Guernsey. The Committee proposes to seek amendment of the law at an early stage.

\section{Resources devoted to banking supervision}

41. Staff resources of the GFSC have continued to grow in line with the size of the finance sector and the responsibilities of the GFSC. The IMF has recommended that the GFSC's Banking Division should carry out a "zero based" analysis of its staff needs, based on the expected number of banks. This has been completed and, as a consequence, an additional analyst has been recruited since the assessment in order to assist the Division to carry out a systematic program of corporate governance and full scope safety and soundness on-site visits to banks.

\section{Regulatory arrangements in banking and securities}

\section{Banking}

42. Following the introduction of the Banking Supervision (Bailiwick of Guernsey) (Amendment) Law, 2003, it is a legal requirement for each Guernsey bank to review, at least annually the responsibilities and conduct of the bank's board of directors with respect to corporate governance principles. Should the review identify any shortcomings, the bank is required to report any findings to the GFSC, together with the details of how it proposes to address the shortcomings.

43. In addition, the law requires Guernsey banks to review, at least annually, their individual loans, asset classification and loss provisions (including on and off balance sheet exposures). Should the review identify any shortcomings, the bank is required to report any findings to the GFSC, together with details of how it proposes to address the shortcomings.

44. GFSC guidance notes entitled "Guidelines for Corporate Governance and Risk Management" are being revised in light of comments received during consultation with banks and will be formally issued as soon as possible, following consideration of the comments arising from the consultation.

45. With regard to policies followed by the GFSC, the scope of on-site credit assessments of banks was extended in early 2003 to give additional emphasis to credit quality and provisioning levels. 


\section{Securities}

46. The States Assembly approved the drafting of separate, explicit, statutory on-site inspection powers with regard to investment licensees in 2002. Consequently, the Financial Services Commission (Bailiwick of Guernsey) (Amendment) Law, 2003 provides the States Assembly with an enabling power to make an Ordinance covering this matter. It is intended that the States Assembly will consider the Ordinance in early 2004. The Protection of Investors (Bailiwick of Guernsey) Law, 1987 already provides the GFSC with comprehensive powers to obtain information and interview investment licensees' staff; onsite inspections have been conducted since 1989.

47. In addition, it is intended to promote an amendment to the Protection of Investors (Bailiwick of Guernsey) Law, 1987, which will provide the GFSC with the power to issue written directives and powers of entry and search after obtaining a warrant from the Bailiff. Similar provisions are already found in the other regulatory legislation administered by the GFSC.

48. With regard to the recommendation that the GFSC should possess a general power enabling it to comment on investment business management and market practice, the GFSC will report to the Advisory and Finance Committee on the recommendation in 2004. There is nothing in the current framework which prohibits the GFSC from commenting on investment business management and market practice should it see fit.

\section{AML/CFT Framework}

49. The authorities have noted the IMF's recommendations and will continue to enhance the framework to counter money laundering and terrorist financing.

50. The Prevention of Corruption (Bailiwick of Guernsey) Law, 2003, which will introduce a statutory offence of corruption, was approved by the States Assembly in September 2003. Once it has received Royal Assent this law will supersede the existing common law on corruption and will assist the Bailiwick to adopt the UN Convention Against Transnational Organized Crime (the Palermo Convention) to Guernsey.

51. In addition, another law, the Criminal Justice (Miscellaneous Provisions) (Bailiwick of Guernsey) Law, will be considered by the States Assembly in early 2004; the States Assembly approved a policy letter incorporating drafting instructions for this law in 2002. The law will include provisions whereby an offence will be committed by a financial services business if it fails to report a suspicious transaction to the Financial Intelligence Service this will replace the existing legal provision, which provides that a reporting of a suspicion is a defense against committing the offence of money laundering.

52. The GFSC has a well established program for the implementation of AML/CFT standards by regulated institutions. It has developed comprehensive Guidance Notes and has established a strong rapport with licensed institutions on AML/CFT issues. The GFSC conducts on-site inspections of financial services businesses' AML/CFT standards. In 2003 
the GFSC issued revisions to the Criminal Justice (Proceeds of Crime) (Bailiwick of Guernsey) Regulations, 2002 and the Guidance Notes on the Prevention of Money Laundering and Countering the Financing of Terrorism for consultation on the technical issues raised by the IMF.

53. The GFSC routinely communicates its policies to the finance sector and is consulting with the finance sector in connection with the publication of a statement on the FATF's June 2003 Recommendation on introduced business.

\section{OBSERVANCE OF FinANCIAL SYSTEM STANDARDS AND CODES: SUMMARY ASSESSMENTS}

\section{A. Basel Core Principles for Effective Banking Supervision ${ }^{6}$}

\section{Institutional setting and market structure}

54. Guernsey issues only one type of banking license, but there are two types of banks: stand-alone and administered. An administered bank uses the services and facilities of a stand-alone bank, which is established and has its own business in Guernsey. The stand-alone bank provides support processing staff, infrastructure, and sometimes systems, to enable an administered bank to function. The primary books and records of the administered bank must be retained in Guernsey. Administered banks are licensed and supervised in the same manner as stand-alone banks, and no distinction is made in the type of license or in the supervision exercised. As of end-October, 2002, there were 69 licensed banks of which 16 were administered banks.

55. The types of banking business conducted in Guernsey include retail, corporate, and international private banking. Private banking business is clearly complementary to the extensive trust, fiduciary, and company service sector in Guernsey. A feature is also that the banks will also accommodate the deposit components of investment portfolios administered and managed by local fiduciaries and private banks. Several banks act as the custodians of assets to the funds administration business and provide deposit facilities and other services to captive insurance companies. Branches of U.K. clearing banks provide, to a large extent, the retail and corporate banking services. A number of licensed banks are subsidiaries of building societies.

56. Guernsey receives substantial amounts of fiduciary deposits from Switzerland. Contractually, they are regarded as interbank deposits based on an interbank contract between the Guernsey bank and the originating bank in Switzerland. Over 40 percent of aggregate bank deposits come from this source, although it does not generate an equivalent amount of income. The deposit gatherers predominantly on-lend the deposits to their head

${ }^{6}$ The assessment was undertaken by Marcel Maes and Jack Heyes (Consultants, MFD). 
offices or place the proceeds in the money markets, principally through London. Many banks offer company and trust services to private clients, in most cases via specialist subsidiaries. There is virtually no U.S. bank business in Guernsey. The main clusters of banks come from Germany, the Netherlands, Switzerland, and the United Kingdom. Two large Bermudan banks also have significant operations in Guernsey.

57. Guernsey's banking business is essentially liability-driven. Most of the banks are deposit gatherers and operate comfortably above their minimum capital adequacy requirements. A small number of banks have active treasury operations dealing with substantial numbers of assets and liabilities. These banks retain sufficient treasury expertise here to be able to participate actively in the chosen segments of their markets: CDs, FRNs, and U.S. Government-guaranteed mortgage paper. Those treasury businesses take advantage of a Guernsey tax concession, which allows a concessionary 2 percent tax rate on referred business.

58. Credit business has become an increasing segment of the banking business in Guernsey that was, until recently, very limited. Banks were essentially driven by deposits with much of that funding on-lent into the money markets and to head office treasury departments. Over the last five years, there has been a gradual, but steadily increasing, amount of locally generated credit business primarily for nonresident clients.

59. Selected outsourcing of back-office operations has been a feature of the Guernsey banking sector. Some banks make use of head office information technology platforms to link up with their central unit typically in Continental Europe, but also U.K. mainland with suitable firewalls to segregate onshore and offshore clients.

60. Banking confidentiality is protected by law in exactly the same manner as in the United Kingdom and other common-law jurisdictions.

\section{General preconditions for effective banking supervision}

61. The Banking Supervision Law, 1994, as amended provides for the regulation of deposit-taking business. It gives the GFSC the ability to set out conditions for issuing licenses. Schedule 3 to the Act sets out the minimum licensing criteria, which include integrity and skill, economic benefit to the jurisdiction, and fitness properness. Only licensed institutions are allowed by Law to accept deposits and the Law provides for the regulation and supervision of such institutions. It also gives the GFSC the ability to impose conditions on licensees, give directions to institutions and provides for penalties for breach of the legislation and for the revocation of licenses. 
Table 2. Balance Sheet of Licensed Banks at Year-End (In Millions of Pounds)

\begin{tabular}{lccc}
\hline & 1997 & 1999 & 2001 \\
\hline Assets & & & \\
Loans, advances, and market loans with banks, etc. & 38,778 & 42,138 & 51,603 \\
British Isles public sector & 4 & 1 & 12 \\
Companies, persons, other & 4,047 & 5,066 & 5,333 \\
CDs & 3,556 & 5,287 & 5,412 \\
Government securities & 5,292 & 3,882 & 10,466 \\
Company shares/securities & 1,483 & 3,657 & 5,401 \\
Other assets & 1,045 & 1,589 & 2,922 \\
Total assets & 54,205 & 61,620 & 81,148 \\
& & & \\
Liabilities & & & \\
Deposits by: & 11,241 & 11,468 & 12,424 \\
Banks, etc. & 36 & 50 & 59 \\
British Isles public sector & 37,162 & 44,598 & 64,728 \\
Companies, persons, other & 4,650 & 1,357 & 1,841 \\
Other liabilities & & & \\
Capital & 1,039 & 4,064 & 2,069 \\
Tier 1 Capital 1/ & 77 & 83 & 27 \\
Tier 2 Capital 2/ & & \\
Total Liabilities and Capital & 54,205 & 61,620 & 81,148 \\
\hline
\end{tabular}

1/ Paid-up share capital and disclosed reserves.

2/ Undisclosed reserves, revaluation reserves, general provisions, debt/equity instruments and subordinated debts.

\section{Principle-by-principle assessment}

62. Prudential regulations and powers are strong and the supervisory process, in general, is effective. This view reflects the mission's assessment that there is a high level of compliance with the Basel Core Principles.

63. There are two principle areas of concern. The first issue relates to the GFSC's functions, which include among others, "the development of finance business in the Bailiwick." This function may give rise to a possible conflict with its other functions. The second issue is that the Banking Division currently has a resource deficit. The mission is concerned that, unless the Banking Division is adequately resourced, the progress made to date will not be sustained, nor will the Division be able to address in an effective manner the mandate envisioned going forward. 


\section{Objectives, autonomy, powers, and resources (CP 1)}

64. Prudential regulations are sound. CP 1 is divided into six principles. The GFSC is to be commended for its continuous proactive attitude taken in order to enhance the Bailiwick's regulatory regime and its endeavor to meet international standards.

65. The GFSC Law gives the Advisory and Finance Committee the right to provide guidance to the GFSC, which could potentially impair its independence. It is therefore recommended to amend the Law and remove this power.

66. The reference to development in the "general functions and statutory functions" of the GFSC may give rise to possible conflict with its other functions. It is essential that the regulator's judgment or freedom of action not be affected by other considerations. For this reason it is recommended that the GFSC Law establishes safety, soundness, and integrity of the financial system as the objectives of the GFSC and eliminate "development" as one of the GFSC functions. Further, there should be no provisions in the Law that could compromise these objectives.

67. The GFSC will have to continue to have due regard for international standards, whether arising from pronouncements by international regulatory bodies or through other international initiatives. The GFSC has indicated that it will do so.

\section{Licensing and structure (CPs 2-5)}

68. An effective licensing authority is in place supplemented by fair and equitable criteria to ensure that a consistent approach is applied to permissible activities, ownership, and investment criteria.

\section{Prudential regulations and requirements (CPs 6-15)}

69. Prudential regulations and requirements compare favorably with international standards and "best practices." No significant weaknesses were noted in the approach applied by the GFSC. However, recommendations to support the evolution of the supervisory process were noted.

\section{Methods of ongoing supervision (CPs 16-20)}

70. The GFSC is to be commended for its constructive approach to supervision and its plan to move to a supervisory approach that is more active and involves a more extensive and substantive approach to its ongoing visitation program. The initial emphasis on AML/CFT complemented by the introduction of credit-risk assessments was sound considering the perception of the risk profile of the industry. Two of the CPs are considered largely compliant while the remaining three are compliant. 
71. The GFSC's Banking Division has a resource deficit and the mission is concerned that if the deficit is not addressed, the Banking Division will not be able to sustain the progress made to date and, therefore, will not be able to meet the progressive mandate that it has outlined. This mandate includes the need for additional efforts to be focused on the assessment of a bank's corporate governance regime and, through this approach, achieve a better understanding of a bank's overall risk-management practices and process of control. The GFSC has issued "Guidelines for Corporate Governance and Risk Management" for consultation. All banks licensed under the amendment to the BSL are required under section $36 \mathrm{C}$ to, inter alia, conduct an annual review of:

- the responsibilities and conduct of the bank's board of directors with respect to corporate governance principles;

- whether there has been effective control by the bank's board of directors over every aspect of risk management;

- $\quad$ the bank's control environment;

- $\quad$ whether the bank's financial record-keeping systems and data systems are reliable; and

- whether any activity has been entered into in the course of the bank's business in respect of which no director of the bank has a sound knowledge.

72. The GFSC issues guidelines to articulate its expectations of a sound corporate governance regime.

73. The mission believes that the GFSC should work with the Guernsey Society of Chartered and Certified Accountants to develop an appropriate methodology that would allow the GFSC to review working papers supporting the work carried out on its behalf. This would allow the GFSC to confirm the reliance placed on the work of external auditors.

\section{Information requirements (CP 21)}

74. The GFSC has emphasized the importance and need for transparency of accounting policies and practices, and conformance with international standards. The GFSC is also to be commended for requiring banks to publish their risk-management policies and practices in the detailed annual statements.

\section{Formal powers of supervisors (CP 22)}

75. Legal provisions are in place that enable the GFSC to take regulatory action against a noncompliant bank. The GFSC has introduced a policy to publicly report the institutions or individuals that are found to be not in compliance with regulatory or legal requirements, 
including providing information on the specific circumstances regarding events of noncompliance and subsequent regulatory actions.

76. The revision of the Companies (Guernsey) Law, 1994, and the proposed amendment to introduce administrative provisions that will include administration to support a bank as a going concern, will add important tools to the GFSC's formal powers.

\section{Cross-border banking (CPs 23-25)}

77. The GFSC applies an effective supervisory process that blends off-site assessment of internationally active banking organizations and regulatory agencies with a visitation program to confirm or otherwise verify the results of the off-site assessment process. It is the policy of the GFSC to license only banks or branches that have parent organizations with an acceptable international presence. This assessment is based on criteria established by the GFSC.

78. Memoranda of Understanding (MOUs) are put in place on request, but the existence of an MOU is not a precursor to allowing the GFSC to exchange information of common interest to another regulator. For the reasons noted, all CPs were considered to be compliant.

79. To support the approach undertaken by the GFSC, we have recommended that a formal confirmation from "home" supervisors be obtained on an annual basis to complement the confirmation of support that is obtained as part of the licensing process. 
Table 3. Recommended Actions to Improve Compliance with the Basel Core Principles

\begin{tabular}{|c|c|}
\hline Reference Principle & Recommended Action \\
\hline CP 1.1 Objective & $\begin{array}{l}\text { The Law has provided the GFSC with the general } \\
\text { function to develop the financial business. This } \\
\text { may conflict with its regulatory and supervisory } \\
\text { functions. } \\
\text { The GFSC Law should, therefore, be amended to } \\
\text { establish safety, soundness, and integrity of the } \\
\text { financial system as the GFSC functions. There } \\
\text { should be no other provisions in the Law that } \\
\text { could potentially compromise these functions. }\end{array}$ \\
\hline CP 1.2 Independence & $\begin{array}{l}\text { The Advisory and Finance Committee's power to } \\
\text { give guidance and directions to the GFSC has the } \\
\text { potential of intruding on the operational } \\
\text { independence of the latter. It is recommended that } \\
\text { the law be amended to remove these powers. } \\
\text { An in-depth analysis of the supervisory objectives } \\
\text { and the means to fulfill those objectives should be } \\
\text { made. The existing Banking Division Manpower } \\
\text { Plan for } 2003-2007 \text { should be revisited } \\
\text { accordingly. }\end{array}$ \\
\hline CP 8 Loan Evaluation \& Loan Loss Provisioning & $\begin{array}{l}\text { Extend current on-site credit risk assessments to } \\
\text { include additional emphasis on credit quality and } \\
\text { provisioning levels. }\end{array}$ \\
\hline CP 14 Internal Control and Audit & $\begin{array}{l}\text { Formalize and distribute Corporate Governance } \\
\text { Guideline. }\end{array}$ \\
\hline CP 16 On-site and Off-site Supervision & $\begin{array}{l}\text { Prioritize the completion of the examination } \\
\text { methodology to allow for full scope safety and } \\
\text { soundness visitations to be carried out } \\
\text { supplemented by more defined quality control } \\
\text { procedures. A dedicated training program directed } \\
\text { at assisting Banking Division staff with the } \\
\text { enhanced accountabilities would be beneficial. } \\
\text { Explore increased synergies with external auditors. }\end{array}$ \\
\hline
\end{tabular}

\section{Authorities' response to the assessment}

\section{Overview}

80. The authorities welcome the IMF's assessment and confirmation that the Bailiwick of Guernsey has achieved a high level of compliance with the Basel Committee Core Principles on Banking Supervision. 


\section{Objectives (CP 1.1)}

81. See paragraph 44 for the response to the recommendation on the GFSC's objectives.

\section{Independence (CP 1.2)}

82. See paragraph 43 for the response to the recommendation on the GFSC's independence.

83. See paragraph 45 for the response to the recommendation on increasing the GFSC's staff resources.

\section{Loan Evaluation and Loan Loss Provisioning (CP 8)}

84. See paragraph 47 for the response to the recommendation on the GFSC's reviews of loan evaluation, asset classification and loan loss provisioning.

\section{Internal Control and Audit (CP 14)}

85. See paragraph 48 for the response to the recommendation to formalize and distribute corporate governance guidelines for internal control and audit.

\section{On-Site and Off-Site Supervision (CP 16)}

86. The GFSC's Banking Division is planning full safety and soundness on-site visits for 2004. The visits will include techniques and practices to confirm or otherwise the existence and application of an effective and comprehensive risk management process and control culture. Additional training of staff in this field of work will continue.

87. Meetings by the GFSC with external bank auditors will be more frequent and scope for increasing synergies will be explored.

\section{Cross Border Banking (CP 25) - see Paragraph 66}

88. With reference to the recommendation that a formal confirmation from home supervisors be obtained on an annual basis to complement the confirmation of support that is obtained as part of the licensing process, the GFSC is contacting all home supervisors. This process will continue on an annual basis.

\section{B. FATF Recommendations for Anti-Money Laundering and Combating the Financing of Terrorism}

89. This Report on the Observance of Standards and Codes for the FATF 40

Recommendations for Anti-Money Laundering and 8 Special Recommendations Combating the Financing of Terrorism was prepared by a team composed of staff of the International 
Monetary Fund, and an expert not under the supervision of Fund staff who was selected from a roster of experts in the assessment of criminal law enforcement. ${ }^{1}$

90. The report provides a summary of the level of observance with the FATF $40+8$ Recommendations, and provides recommendations to strengthen observance.

\section{Information and methodology used for the assessment}

91. In preparing the detailed assessment, Fund staff reviewed the relevant AML/CFT laws and regulations, supervisory and regulatory systems in place to deter money laundering, as well as FT among prudentially regulated FIs. In addition, the Fund reviewed the regulatory systems in place for trust and company service providers that were in a transitional stage toward full regulation at the time of the assessment. An expert not under the supervision of the Fund reviewed the capacity and implementation of criminal law enforcement systems. The field work was undertaken over the course of two visits to Guernsey.

\section{Criminal justice measures and international cooperation}

92. Guernsey has a generally adequate framework for the criminalization of ML and terrorist financing. The Vienna Convention has been ratified on its behalf by the United Kingdom and a request has been submitted for a similar ratification of the Convention for the Suppression of the Financing of Terrorism. The GFSC has powers to impose a number of sanctions on banks, investment businesses, fiduciaries, and insurance businesses.

93. ML is criminalized and relates to the proceeds of all serious offenses, including financing terrorism. The FT is also criminalized and is consistent with the definition set out in the Convention for the Suppression of the Financing of Terrorism.

\footnotetext{
${ }^{1}$ The assessment was undertaken by Ian Carrington (MFD), Ross Delston (Consulting Counsel LEG), with the assistance of Stuart Yikona (Technical Assistance Officer LEG). Detective Chief Superintendent Felix McKenna (Criminal Asset Bureau, Ireland), was the independent anti-money laundering expert (IAE). Portions of the assessment attributable to the IAE appear in italicized text.
} 


\section{Confiscation of proceeds of crime or property used to finance terrorism}

94. Laws provide for the confiscation of laundered property, proceeds from and instrumentalities used in or intended for use in Guernsey with respect to any ML offense. There is also provision for the forfeiture of property that are the proceeds of or intended for use in FT.

95. There is protection for the rights of bona fide third parties in the case of restraint orders. In addition, where the Court is satisfied that a victim of any relevant criminal conduct has instituted, or intends to institute, civil proceedings against the defendant in respect of loss, injury, or damage sustained in connection with that conduct, the Court does not have to make a confiscation order in the total sum that is available to be realized.

\section{The FIU and processes for receiving, analyzing, and disseminating intelligence at the domestic and international levels.}

96. The Financial Intelligence Service (FIS) is Guernsey's FIU and is an independent unit of the Guernsey Police Force and Officers of the Customs and Excise office, jointly staffed by both the Police and Customs. FIs are required to report to a police officer (a defined term that includes customs officers) transactions suspected of stemming from criminal activity or used to finance terrorism. Reporting parties are required to submit suspicious reports where such party knows or suspects that a person is engaged in ML or the FT. In 1998, Guernsey's FIU became a member of the Egmont Group, in which it plays an active role.

97. The FIS does not have the power in law to demand additional information from reporting parties. According to the authorities, in practice it does request such information and, in most cases, the required information is provided.

98. Statistics are kept by FIS/FIU as part of its function relating to amounts of property frozen, seized, and confiscated relating to proceeds of crime, drug trafficking, money laundering, and financial terrorism. Records are kept and recorded on all referrals made by the FIS/FIU to other competent authorities.

99. The FIS/FIU as currently structured and funded is capable of performing its functions; however, it is not working at maximum capacity due to shortage of staff and a dramatic increase in workload. The FIS/FIU requires two further financial investigators to bring the unit to the recommended and approved strength, and requires the support of a financial analyst and an administrative assistant.

\section{Law enforcement and prosecution authorities, powers, and duties}

100. The responsibility to ensure that ML and FT offenses are properly investigated rests with the Police and Customs and Excise. The FIS/FIU is also able to carry out this task as it is staffed with personnel from Police and Customs and Excise. 
101. Prior to obtaining/serving production orders or warrants, the consent/authority of a law officer is required. The structure of law enforcement ensures that all offenses are properly investigated.

102. Law enforcement authorities are able to compel production of bank records and other records maintained by FIs through lawful process.

\section{International cooperation}

103. There are laws and procedures that provide for mutual legal assistance regarding the use of compulsory measures, including the production of records and search of persons and premises. The laws allow for the widest possible range of mutual legal assistance in AML/CFT matters.

104. Production orders or warrants may be issued to obtain records from FIs or private individuals. There are laws and procedures that provide for mutual legal assistance regarding the use of compulsory measures, including the production of records, and search of persons and premises. They allow for the widest possible range of mutual legal assistance in AML/CFT matters.

105. The principal concerns are:

- $\quad$ There is no provision in the Criminal Justice (Proceeds of Crime) (Bailiwick of Guernsey) Law 1999, as amended, that makes it a crime to fail to report a suspicious transaction, as in the DT Law, rather than as a defense to the crime of money laundering. In addition, there is no requirement in law that STRs should be submitted to the FIS.

- In light of its increasing workload, the resources available to the FIS are inadequate.

- While the GFSC conducts on-site inspections to licensees and the POI contains provisions enabling the GFSC to obtain information and interview staff, the law does not contain a specific provision permitting the GFSC to enter a licensee's premises.

\section{Preventive measures for financial institutions}

106. The GFSC has a well-established program for the implementation of AML/CFT standards by prudentially regulated institutions. It has developed comprehensive Guidance Notes (Notes) and has established a strong rapport with licensed institutions on AML/CFT issues. Additional periodic guidance is provided through a number of mechanisms, including the issuance of "Business From Sensitive Sources Notices" and meetings with industry representatives. Since 1999, the GFSC has instituted a program of on-site visits to assess compliance and has visited the vast majority of licensees. The GFSC has also been actively involved in facilitating the provision of training for the staff of regulated institutions. 
107. The Policy and International Affairs Division has principal responsibility for AML/CFT issues. The Deputy Director is assisted by a consultant at the level of Assistant Director who is devoted to AML/CFT issues on a full-time basis. Subsequent to the mission, this officer left the GFSC. A senior analyst has joined the staff of the Division and is devoted fully to matters related to AML/CFT. The GFSC has also retained the services of an external consultant to assist in its AML/CFT program. The Regulations require the GFSC to train its staff on AML issues. The GFSC has held formal in-house training for its staff, with the most recent training prior to the mission having taken place in July 2002.

108. All Divisions undertake their own AML/CFT surveillance activity which includes on-site visits scheduled on a two-year cycle. The Banking Division commenced on-site assessments of licensees in 1999. The other Divisions commenced reviews in 2000.

109. In December 2000, Guernsey, in conjunction with Jersey and the Isle of Man, developed the consultation document entitled, "Overriding Principles For a Revised Know Your Customer Framework." On the basis of responses to the document, the FSCs have issued a paper outlining the direction to be taken in the AML legal and regulatory frameworks in each jurisdiction. This paper, which does not replace the existing Guidance Notes, focuses on issues related to the verification of customer identity.

110. Among the many aspects of identity verification addressed in the paper are the issues of introduced business and the verification of identity of customers whose relationship with FIs pre-date the all-crimes AML legislation (Progressive Program). Unlike the existing framework where an introducer can hold verification documents to be made available to the "accepting party" on request, the paper envisages that an "accepting party" will always hold either originals or copies of these documents. In terms of the Progressive Program, the paper envisages that where FIs discover any deficiencies in existing verification documents, they should seek to obtain necessary information to address the deficiency. It proposes that this work be undertaken on the basis of risk prioritization and trigger events.

111. Regulated institutions in the banking, insurance, and securities sectors demonstrate a high level of compliance with the assessed criteria. Institutions visited generally had well-documented procedures and practices, and had developed training programs for their staff.

112. The principal areas of concern are the following:

- $\quad$ There are a number of areas in which the Notes do not clearly indicate the standard that is expected of institutions and other parties covered by the AML/CFT legislation.

- $\quad$ Visits to FIs revealed a wide range of KYC practices in relation to the issues addressed by the Overriding Principles Paper. The GFSC should redouble its efforts to achieve a greater degree of uniformity in the practices used by financial services businesses. This is particularly needed in matters related to introduced business and the retroactive verification of customer identity. 
- Notwithstanding the fact that the GFSC has been able to undertake on-site visits of investment businesses and the POI contains provisions for obtaining information and interviewing staff, the POI does not give the GFSC the express right to enter premises of licensees. This contrasts with the legislation for banking, fiduciary, and insurance business, which gives the Commission the express right to enter the premises of licensees.

113. The GFSC has started the process of regulating trust and company service providers. The licensing process has not been completed but all persons undertaking these activities are covered by Guernsey's AML/CFT framework. Visits to these entities indicated a high level of compliance with AML/CFT requirements.

\section{Summary assessment against the FATF recommendations}

114. Guernsey has a sound legal and institutional AML/CFT framework with high levels of compliance observed among regulated institutions. This report however makes a number of recommendations for further strengthening of the regime. Table 4 summarizes actions required in relation to the $40+8$ recommendations. 
Table 4. Recommended Action Plan to Improve Compliance with the FATF Recommendations

\begin{tabular}{|l|l|}
\hline \multicolumn{1}{|c|}{ Reference FATF Recommendation } & Recommended Action \\
\hline 40 Recommendations for AML & $\begin{array}{l}\text { The relevant laws should be amended to explicitly require that } \\
\text { (FATF 10-13) }\end{array}$ \\
$\begin{array}{ll}\text { customer identification procedures be followed. } \\
\text { The GFSC has already undertaken considerable work to direct } \\
\text { FIs toward the customer identification standards proposed by } \\
\text { the Position Paper. It is nevertheless recommended that these } \\
\text { efforts be redoubled to ensure a greater degree of consistency } \\
\text { in the approach adopted by licensees. }\end{array}$ \\
\hline $\begin{array}{l}\text { Increased diligence of FIs (FATF 14-19) } \\
\text { Measures to cope with countries with insufficient should be adopted along the lines of the Draft } \\
\text { AML measures (FATF 20-21) } \\
\text { crime to fail to report a suspicious transaction, as in the DT } \\
\text { Law, rather than as a defense to the crime of money } \\
\text { laundering. }\end{array}$ \\
$\begin{array}{l}\text { Consideration should be given to a requirement that all } \\
\text { Guernsey FIs apply Guernsey legal and regulatory } \\
\text { requirements in respect of AML/CFT to their branches and } \\
\text { subsidiaries outside of Guernsey. The GFSC has issued draft } \\
\text { revised regulations and Notes for consultation that will } \\
\text { address this concern. }\end{array}$ \\
\hline $\begin{array}{l}\text { 8 Special recommendations on terrorist } \\
\text { financing }\end{array}$ & $\begin{array}{l}\text { The International Convention for the Suppression of the FT } \\
\text { I. Ratification and implementation of UN } \\
\text { Instruments }\end{array}$ \\
\hline VII. Wire transfers & $\begin{array}{l}\text { Within the two-year period referred to by FATF, the relevant } \\
\text { laws should be amended to require that accurate and } \\
\text { meaningful originator information on funds transfers remain } \\
\text { with the transfer throughout the payment chain, and that FIs } \\
\text { give enhanced scrutiny to wire transfers that do not contain } \\
\text { complete originator information. }\end{array}$ \\
\hline
\end{tabular}

\section{Other Recommended Actions}

115. Other recommendations arising from the AML/CFT assessment appear in Table 9 of Volume II. 


\section{Authorities' response to the assessment}

\section{Overview}

116. The authorities welcome the IMF's assessment and confirmation that the Bailiwick of Guernsey has a sound legal and institutional AML/CFT framework with a high level of compliance with the Financial Action Task Force Recommendations on Money Laundering and the Special Recommendations on Terrorist Financing.

\section{Customer Identification and Record Keeping Rules (FATF 10-13)}

117. The Criminal Justice (Proceeds of Crime) (Bailiwick of Guernsey) Regulations, 2002 already contain detailed customer identification requirements, which must be followed by financial services businesses. Failure to comply with the Regulations is an offence. The IMF's comment about the documentary requirements for legal entities will be considered as part of the changes to the Regulations and the Guidance Notes arising from the Financial Action Task Force's new Recommendations (issued in June 2003).

118. The GFSC routinely communicates its policies to the finance sector and is consulting with the finance sector in connection with the publication of a statement on the FATF's June 2003 Recommendation on introduced business.

\section{Increased diligence of FIs (FATF 14-19)}

119. See paragraph 55 for the response to the recommendation on the reporting of suspicious transactions to the Financial Intelligence Service.

\section{Measures to Cope with Countries with Insufficient AML Measures (FATF 20-21)}

120. Proposed changes to the Criminal Justice (Proceeds of Crime) (Bailiwick of Guernsey) Regulations, 2002 and the Guidance Notes on the Prevention of Money Laundering and Countering the Financing of Terrorism, to include additional detail on the application of AML/CFT standards to the branches and subsidiaries of Guernsey financial services businesses have been issued to the finance sector for consultation.

\section{Ratification and Implementation of UN Instruments (FATF Special Recommendation I)}

121. With the enactment of the Terrorism and Crime (Bailiwick of Guernsey) Law, 2002 all relevant legislation to satisfy the International Convention for the Suppression of the Financing of Terrorism has been enacted. Application has been made for the Convention to be extended to Guernsey. 


\section{Wire Transfers (Special Recommendation VII)}

122. Proposed changes to the Criminal Justice (Bailiwick of Guernsey) Regulations, 2002 and the Guidance Notes in respect of the requirements for originator information to remain with wire transfers have been issued to the finance sector for consultation.

\section{IAIS Core Principles ${ }^{7}$}

\section{General}

123. This assessment of the current state of Guernsey's compliance with the IAIS Core Principles has been completed as part of the IMF Offshore Financial Sector (OFC) report.

\section{Institutional and macroprudential setting-overview}

124. Guernsey is one of the largest captive insurance centers in the world. The premium income for all international insurance companies in Guernsey in the year 2002 was $£ 2.96$ billion. They held assets of $£ 12.16$ billion and capital of $£ 5$ billion.

125. The GFSC is the sole regulator with responsibility for the financial services market. Insurance businesses, including company managers and intermediaries, are supervised by the Insurance Division of the GFSC. The basis of insurance supervision is the Insurance Business (Bailiwick of Guernsey) Law, 2002 (IB Law), the Insurance Managers and Insurance Intermediaries (Bailiwick of Guernsey) Law (IMII Law), and the Regulations, Ordinances, Codes, and Guidance Notes based on these Laws.

126. This relatively new legislative framework was adopted by Guernsey to consolidate the 1986 Law and its amendments to comply with the IAIS Core Principles; to ensure consistency with other more recent GFSC Laws; to incorporate changes recommended by the Insurance Law Review Committee (established in 1993); and to comply with human rights legislation.

\section{General preconditions for effective insurance supervision}

127. The preconditions for an effective insurance supervision are satisfied through a well-developed infrastructure:

- the legal framework in place is consistent, modern, and in compliance with international standards;

\footnotetext{
${ }^{7}$ The assessment was undertaken by Helmut Müller (consultant MFD).
} 
- $\quad$ the court system is efficient and reliable;

- $\quad$ the applied accounting standards are internationally accepted;

- the actuarial and auditing professions are available and apply recognized principles;

- $\quad$ an efficient financial market (banks and investment funds) exists; and

- $\quad$ sound and effective macroeconomic policies are in place that allow the insurance industry to operate in a stable environment.

128. The GFSC has the information and intervention powers that are necessary to fulfill its functions. The Insurance Division has a staff of 14, comprising a Director, Deputy Director, an actuary, 8 analysts, a consultant, and 2 support staff. The personnel are professionally qualified.

\section{Principle-by-principle assessment}

129. Guernsey has achieved a very high standard of observance with the IAIS Insurance Core Principles. The insurance framework is very new. The main laws were recently amended. One of the reasons to amend the laws was to reach compliance with international standards like the IAIS Core Principles.

\section{Organization (Principle 1)}

130. In order to observe this principle, the supervisor has to be operationally independent from the government and the industry. The government has the right to give written guidance and direction of general character to the GFSC. This possibility may impair the operational independence of the insurance supervisor, but had not in fact done so. There is no need for intervention possibilities by the government. It is, therefore, recommended that this possibility be deleted.

131. The GFSC Law provides in Section 2, "The general functions of the Commission are to take such steps as it considers necessary or expedient for the development and effective supervision of finance business in the Bailiwick." "Under the GFSC Law, "development" and

\footnotetext{
8 The Law elaborates in Section 2A that "development includes, without limitation, the establishment and ongoing support of bodies and organizations the functions of which include or are important or relevant to: (i) the development of finance business in the Bailiwick and of that sector of the economy which carries on finance business with the general function to develop the financial business of the islands; (ii) the improvement of the infrastructure of or serving that sector of the Bailiwick economy which carries on finance business; (iii) the protection of the public; and (iv) the protection and enhancement of the Bailiwick as a financial center."
} 
"effective supervision" are functions of the GFSC, and the Law does not provide a clear way to resolve potential conflicts between these objectives. The current Law has a potential to compromise the judgment and the independence of the supervisor and, therefore, should be amended. 
132. The GFSC Law should be amended in order to incorporate the power to impose civil money penalties (administrative fines) on companies and controllers.

133. The personnel within the Insurance Division possess a wide number of professional qualifications and, additionally, a wide variety of financial sector and regulatory experience. The number of staff has increased steadily. The new laws aim to strengthen supervision. Insurance has become more volatile and the competition has hardened. The number of insurance companies has increased. Onsite inspections have to be intensified. Under these circumstances, it is recommended to increase the number of staff as proposed by the GFSC (at least a second actuary and two more analysts). Since the mission, both on-site inspections and the number of staff have increased. The staff increase includes a trainee actuary and the two additional analysts.

\section{Licensing and changes in control (Principles 2 and 3)}

134. The legal mechanism for the licensing of insurance business, insurance managers, and insurance intermediaries in or from within Guernsey is provided by the IB and IMII Laws. Licensing provisions, responsibilities, and tasks specified are conferred upon the GFSC. The laws contain detailed minimum criteria for licensing. The GFSC will not grant a license unless it is satisfied that the criteria have been met. The supervisor has the power to suspend or to revoke a license in a variety of circumstances, including where the insurer has been involved in substantial irregularities.

135. The laws place an obligation on controlling shareholders, including the parent corporations, to notify and seek the prior approval of the GFSC when there is to be change in the control over a regulated FI. In conducting its review, the GFSC utilizes not only its own data but also has access to information held by the Shared Intelligence System, Lexis Nexis, the Financial Fraud Information Network, and various websites such as those of the SEC and FBI.

\section{Corporate governance and internal control (Principles 4 and 5)}

136. The Licensed Insurer's Corporate Governance Code of Conduct (LICG Code), which came into force in November 2002, sets out sound principles of practice relating to corporate governance for licensed insurers. A failure to comply with the LICG Code is an offense under the IB Law. Compliance is required by December 31, 2003.

137. The LICG Code requires the Board of Directors to establish internal control procedures for the purposes of conducting the business with regard to its nature and scale. In establishing such procedures, the Board is required to provide the GFSC with copies of the inaugural meeting identifying such internal controls. 


\section{Prudential rules (Principles 6-10)}

138. Approved assets are principally restricted to trading assets and high-quality investments readily realizable in recognized markets.

139. The rules relating to the valuation of liabilities are detailed in the IB Law, which provides that liabilities are to be determined in accordance with recognized accounting standards (i.e., U.K. GAAP). In the case of long-term insurance, an annual actuarial investigation is required and a report is made in accordance with relevant professional standards of the Institute or Faculty of Actuaries.

140. The IB Law provides, together with the relevant regulations, the detailed requirements for a licensed insurer to secure that its liabilities under contracts of insurance entered into by it are covered by assets of appropriate safety, yield, and marketability.

141. The Law provides that an insurer shall maintain paid-up capital of not less than the minimum capital requirement. This minimum for insurers writing general insurance is $£ 10,000$ and $£ 250,000$ for insurers writing long-term insurance.

142. This minimum capital, as well as the minimum solvency margin, is rather low in comparison with the minimum level, for instance, in the EU. However, the GFSC uses regularly the legal provisions available to modify these solvency requirements taking into account the size, complexity of business, and the risk exposure of the company, for the licensing procedure, as well as for ongoing supervision. In doing so, the solvency requirements in practice are usually much higher than the minimum amount. Nevertheless, it should be considered to increase these minima from time to time following the economic environment and development worldwide.

143. An insurer can only trade in approved derivatives. The regulations detail the criteria, which must be met for a derivative to be treated as approved. The purpose is to avoid speculative transactions. Any insurer who trades in derivatives in breach of the laws or regulations is guilty of an offense.

144. The reinsurance program as part of the business plan includes all details of the reinsurance arrangements. The IB Law requires a declaration of reliance on reinsurers in such form as the GFSC may demand. If a proposed reinsurer was unacceptable to the GFSC, a condition would be imposed on the licensed insurer to require it to change its proposed reinsurer. A pure reinsurer carrying on business in or from Guernsey will require a license from the GFSC and, in being granted a license, will be subject to the same regulations and rules as those governing a direct insurer. At the present, there is no professional reinsurer licensed in Guernsey. 


\section{Market conduct (Principle 11)}

145. In the Principles of Finance Business, the GFSC requires the licensees to observe high standards of integrity and fair dealing in the conduct of business and to act with due skill, care, and diligence. In order to comply with the Principles, the key functionaries must be fit and proper. If that is not the case, the GFSC is authorized to refuse to grant or to revoke a license.

146. The GFSC does not act as ombudsman or arbitrator where complaints arise, but follows up the complaint with the licensee and ensures that it is dealt with at a senior level.

147. The position of a financial services ombudsman is in the process of being created.

\section{Monitoring, inspection, and sanctions (Principles 12-14)}

148. The IB Law requires an insurer in respect of its financial year to prepare an annual report and financial accounts, and to submit these along with the related auditor's report and actuarial report (if applicable) to the GFSC within four months of the financial period to which the accounts relate.

149. Similar information is required from licensed insurance managers and insurance intermediaries.

150. The accounts are required to be drawn up in accordance with Recognized Accounting Standards (U.K. GAAP or other internationally accepted standards).

151. The GFSC has the power to conduct on-site inspections at such times and intervals as it thinks fit and where it considers it will be desirable to do so for the protection of the interests of the policyholder or the reputation of Guernsey as a financial center. In practice, the GFSC carries out visits on a three-year rolling program for all licensees. In 2002, a total of 26 inspections were undertaken. They intend to intensify on-site inspections.

152. The GFSC has a range of powers to take remedial actions in the interests of the policyholders. It relies upon having detailed information, proactive supervision, and a significant range of possible remedial action to enable it to take effective, timely, and appropriate action. For serious offenses, fines and prison sentences, as well as compulsory winding up, are available. To complete the range of sanctions, it is recommended that the GFSC impose civil money penalties (administrative fines) following international standards of financial services supervision.

Cross-border operations, supervisory coordination and cooperation, and confidentiality (Principles 15-17)

153. All insurance activities conducted in or from Guernsey must be licensed and supervised by the GFSC. The supervisor can refuse to grant a license to a foreign insurer under the same circumstances given in the case of a domestic insurer. 
154. The GFSC has the power to and will cooperate with the home country supervisor, should they wish for instance to undertake on-site inspections within Guernsey.

155. The GFSC has a range of gateways to enable it to share information domestically and internationally. Indeed, the GFSC has a long experience of cooperation with regulators in other countries in matters of investigation and enforcement. It has MOUs with numerous foreign supervisory authorities.

156. The GFSC law imposes duties of confidentiality on the GFSC and its staff. A person who fails is guilty of an offense. The cases in which the supervisor is permitted to disclose or share information are set out in the IB, IMMI, and FSC laws. These include the disclosure and sharing of information with other supervisors. The confidentiality requirements apply also to information that the GFSC receives from other supervisors abroad.

Table 5. Recommended Action Plan for Observance of IAIS Insurance Core Principles

\begin{tabular}{|l|l|}
\hline \multicolumn{1}{|c|}{ Reference Principle } & \multicolumn{1}{c|}{ Recommended Action } \\
\hline CP 1 Organization of an Insurance Supervisor & $\begin{array}{l}\text { In order to strengthen the operational independence } \\
\text { of the GFSC, the mission recommends that the GFSC } \\
\text { Law be amended to remove the power of the } \\
\text { Advisory and Finance Committee to provide } \\
\text { guidance and direction to the GFSC. } \\
\text { The GFSC Law should establish safety, soundness, } \\
\text { and integrity of the financial system as the objectives } \\
\text { of the GFSC, and eliminate "development" as one of } \\
\text { the GFSC functions. Further, there should be no } \\
\text { provisions in the Law that could potentially } \\
\text { compromise the above-stated objectives. This would } \\
\text { provide a clear legal framework that would avoid } \\
\text { potential conflicts in the functions of the GFSC. The } \\
\text { attainment and sustainability of these objectives will } \\
\text { enhance the reputation and contribute to the } \\
\text { development of the financial system in Guernsey. } \\
\text { The number of staff has to be increased. }\end{array}$ \\
\hline CP 8 Capital Adequacy and Solvency & $\begin{array}{l}\text { Increase the legally required solvency minimum. } \\
\text { CP 14 Sanctions }\end{array}$ \\
$\begin{array}{l}\text { Complete the range of sanctions by the power of the } \\
\text { supervisor to impose penalties (administrative fines). }\end{array}$ \\
\hline
\end{tabular}




\section{Authorities' response to the assessment}

\section{Overview}

157. The authorities welcome the IMF's assessment and confirmation that the Bailiwick of Guernsey has achieved a high level of compliance with the IAIS Core Principles.

Organization (ICP 1)

158. See paragraph 43 for the response to the recommendation on the GFSC's independence.

159. Since the IMF's assessment the staff of the GFSC's Insurance Division has increased to include an assistant actuary and two analysts, as recommended by the IMF.

Prudential Rules (ICP 8)

160. With regard to solvency requirements, provisions exist within the Insurance Business (Bailiwick of Guernsey) Law, 2002 for the GFSC to modify the solvency requirements of each insurer depending on the size, nature and complexity of the risks being written. Solvency levels for individual insurers are set on this basis. The GFSC's requirements can be imposed at the licensing stage as well as on an ongoing basis. In practice, this means that solvency requirements are much higher than the minimum legal levels set under the law. The solvency of individual insurers is continually monitored by the GFSC.

Imposition of Penalties (ICP 14)

161. The GFSC will report to the States of Guernsey Advisory and Finance Committee in 2004 on the recommendation concerning the imposition of penalties.

\section{IOSCO Objectives and Principles of Securities Regulation ${ }^{9}$}

\section{General}

162. This report has been prepared in the course of a formal assessment by the IMF of the regulatory and supervisory arrangements of the Bailiwick of Guernsey for its financial sector. In the report, the mission reviews the rules of law and practice about the regulation of securities and investments and, for this purpose, considers whether the Bailiwick has implemented the International Organization of Securities commissions (IOSCO) Objectives and Principles of Securities Regulation. The IOSCO, when adopting these Objectives and

\footnotetext{
${ }^{9}$ The assessment was undertaken by John Farrell (Consultant, MFD).
} 
Principles, stated its commitment to "high regulatory standards and effective international cooperation" and these are central to the present assessment.

\section{Information and methodology used for assessment}

163. In essence, the assessment has been undertaken by analyzing the rules of law, the statements of best practice, and the evidence of current practice in the Bailiwick and evaluating them against the 30 IOSCO Principles.

164. The mission reviewed many background documents before or in the course of the assessment. These included the IMF's own guidance notes on the assessment process and procedures; various IOSCO reports and resolutions; relevant publications of OECD; selected Bailiwick legislation; regulations; ordinances; rules; codes and guidance statements; various documents on the GFSC website; the IOSCO self-assessments prepared by the GFSC; and various operational documents of the GFSC. In reviewing this material, the mission paid close attention to the explanatory notes accompanying the IOSCO Statement of Objectives and Principles. It also considered the MFP Transparency Code. The mission had extensive discussions with representatives of the government; the FSC; professional bodies (including those representing independent auditors and legal advisers of firms licensed by the GFSC); industry associations; and a number of firms representative of the various categories of firms licensed to undertake securities and investment business. In the time available, the mission did not have the opportunity to confer with independent commentators.

165. The most important types of investment business carried on in the Bailiwick are:

(i) management, administration, and custody of collective investment funds (open and closed-ended);

(ii) discretionary asset management;

(iii) nondiscretionary asset management;

(iv) stock broking; and

(v) provision of investment advice.

166. As at June 30, 2002, there were 428 entities licensed to carry on investment business, of which 403 were companies incorporated in the Bailiwick, one Bailiwick partnership, and 24 branches of international institutions. Clients of investment businesses include local and overseas residents, local and overseas institutions, and professional firms. The geographical spread of clients is said to be diverse. 


\section{General preconditions for effective securities regulation}

167. The GFSC has adopted as its primary objective:

"to regulate the Bailiwick's finance sector to international standards and, by doing so, to protect depositors, investors, policy holders, other customers, and the public."

168. Market access is determined by reference to the securities regulatory system and the decisions of the GFSC. The mission is not aware of any particular barriers to the entry or exit of market participants other than those which are incidental to the operation of the regulatory system. The Bailiwick does not have explicit rules of statute law about competition. Nevertheless, it is the team's impression that there is a diversity of market participants engaged in investment business.

169. As noted above, the Bailiwick has a conventional framework of general business law, including a common-law system. Securities law is backstopped by rules of law about contract, tort, and property, and about serious fraud and other crimes involving fraud and deceit. Securities law is also dependent on mature rules of law about the constitution of entities that issue securities for subscription; in particular, company law and partnership law. Guernsey and Alderney both have mature rules about the formation and administration of companies and partnerships.

170. The Bailiwick depends for its ability to develop as an international finance center on the quality of its regulation, the expertise of its people, the cost of doing business there, and its tax regime. It has encountered criticism in the past, particularly from neighboring countries, about its tax regime. The Bailiwick authorities consider it all the more important in the circumstances to have and to be seen to have soundly based law and procedures for the supervision and regulation of market participants, and to cooperate and to be seen to cooperate with equivalent authorities in other jurisdictions.

171. The Bailiwick also depends for its ability to develop as a finance center on its willingness to cooperate more generally with others on regulatory matters. The GFSC has direct bilateral relations with a number of regulators in overseas jurisdictions under MOUs on cooperation in the regulation of financial markets and institutions.

\section{Principle-by-principle assessment}

172. Guernsey has achieved a high standard of compliance with the IOSCO Principles. The GFSC has a good range of regulatory powers. Its Investment Business Division, with a staff of 19 people and shortly to rise to 24 , seems resourced appropriately and able to maintain consistent standards of supervision in the Bailiwick. 


\section{Regulator (Principles 1-5)}

173. The responsibilities of the GFSC are clearly stated. It has adequate powers and proper resources to do its work, has adopted clear and consistent processes, and its staff has adopted high professional standards. The mission gave particular consideration to the question whether the GFSC is operationally independent. There are circumstances in which the government may issue guidance or directions on matters of policy or on the manner in which the GFSC carries out its functions.

\section{Self-regulatory organization (Principles 6-7)}

174. There is one self-regulatory organization (SRO), the CISX, in respect of its members and listed issuers. The regulatory system makes appropriate use of the CISX as an SRO and the GFSC maintains oversight with respect to standards of fairness.

\section{Enforcement (Principles 8-10)}

175. The GFSC has powers of inspection, investigation, and surveillance. However, it does not have powers of on-site inspection in respect of people who do not hold licenses and it does not have adequate powers of entry and search.

\section{Cooperation (Principles 11-13)}

176. The GFSC has wide powers to share information, both public and nonpublic, with domestic and foreign counterparts. It has entered into 11 MOUs with foreign counterparts, and is at present negotiating another 4 MOUs. Two of these MOUs were signed subsequent to the mission. Typically, these aim "to establish a framework for mutual assistance and to facilitate the exchange of information between the commissions to enforce or secure compliance with any laws or regulations of their respective jurisdictions."

\section{Principles for Issuers (Principles 14-16)}

177. The GFSC works to achieve full, accurate, and timely disclosure of financial and other information to investors, and fair and equitable treatment for investors. It has powers and resources for these purposes. Accounting and auditing standards are of an internationally acceptable quality. Nevertheless, the Bailiwick should commit resources to its review of accounting and auditing standards, and the review of auditor performance, recognizing that these are under careful scrutiny internationally.

\section{Collective investment schemes (Principles 17-20)}

178. The Bailiwick has extensive rules of law about collective investment schemes, including standards for operators; rules for legal form and structure; the segregation and protection of client assets; disclosure and the basis for asset valuation; and unit pricing. The GFSC maintains an active program of regulation and supervision. 


\section{Market intermediaries (Principles 21-24)}

179. There are minimum entry standards for market intermediaries, ongoing capital, and other prudential requirements and standards for internal organization and operational conduct. The mission does not consider that the Bailiwick has a complete procedure for dealing with the failure of a market intermediary and recommends that the Bailiwick consider the powers that should be available to the GFSC for this.

\section{Secondary market (Principles 25-30)}

180. The establishment of a trading system is subject to regulatory authorization and oversight. There is ongoing supervision. Regulation promotes transparency of trading. The clearance and settlement system is subject to oversight and designed to ensure fairness and efficiency.

181. The Bailiwick does not have explicit regulation to ensure the proper management of large exposures, default, and market disruption.

Table 6. Recommended Plan of Actions to Improve Observance of the IOSCO Objectives and Principles of Securities Regulation

\begin{tabular}{|c|c|}
\hline Reference Principle & Recommended Action \\
\hline CP 1 Principles Relating to the Regulator & $\begin{array}{l}\text { 1. We note that the IOSCO Principles are backed by the } \\
\text { three IOSCO Objectives : } \\
\text { - the protection of investors; } \\
\text { ensuring markets are fair, efficient, and } \\
\text { transparent; and } \\
\text { reducing systemic risk. } \\
\text { We recommend that the GFSC consider in any review of } \\
\text { its statement of responsibilities whether any aspect of its } \\
\text { commitment to these objectives should be more explicitly } \\
\text { recognized. } \\
\text { We consider that the GFSC would be better placed to } \\
\text { undertake work under the Borrowing (Control) Law if its } \\
\text { powers were more up-to-date and better integrated with } \\
\text { its other powers. The GFSC has informed us that it is } \\
\text { proposing to review this Law, in the context of a more } \\
\text { general review of Company Law. We recommend that } \\
\text { the GFSC proceed to undertake this work. }\end{array}$ \\
\hline $\begin{array}{l}\text { CP } 8 \text { Principles for the Enforcement of } \\
\text { Securities Regulation }\end{array}$ & $\begin{array}{l}\text { We recommend that the GFSC have access to powers of } \\
\text { entry and search, directly or through another agency such } \\
\text { as the Law Officers. } \\
\text { We recommend that the GFSC seek a general power to } \\
\text { comment on investment business management and } \\
\text { market practice. }\end{array}$ \\
\hline
\end{tabular}




\begin{tabular}{|c|l|}
\hline \multicolumn{1}{|c|}{ Reference Principle } & \multicolumn{1}{c|}{ Recommended Action } \\
\hline CP 16 Principles for Issuers & $\begin{array}{l}\text { The source of authority for financial reporting and audit } \\
\text { standards, and for the review of auditor performance is } \\
\text { under careful review internationally. The mission } \\
\text { recommends that the GFSC, the accounting profession } \\
\text { and others should continue their ongoing consideration of } \\
\text { this matter. }\end{array}$ \\
\hline CP24 Principles for Market Intermediaries & $\begin{array}{l}\text { We recommend that the Bailiwick review powers which } \\
\text { are available to the GFSC to deal with the failure of an } \\
\text { intermediary. }\end{array}$ \\
\hline
\end{tabular}

\section{Authorities' response to the assessment}

\section{Overview}

182. The authorities welcome the IMF's assessment and confirmation that the Bailiwick of Guernsey has achieved a high level of compliance with the IOSCO Objectives and Principles of Securities Regulation.

Principles Relating to the Regulator (Principle 1)

183. See paragraph 44 for the response to the recommendation on the GFSC's function.

184. The Control of Borrowing (Bailiwick of Guernsey)(Amendment) Ordinance, 2003 provides the GFSC with explicit authority to issue guidance on the investment supervisory standards it has adopted under the Control of Borrowing regime. The regime is being reviewed as part of a review of company law and a consultation document will be issued in 2004.

\section{Principles Relating to the Regulator (Principle 2)}

185. See paragraph 43 for the response to the recommendation on the GFSC's independence.

\section{Principles for the Enforcement of Securities Regulation (Principle 8) - Paragraph 104}

186. See paragraphs 50,51 and 52 for the response to the recommendation on the GFSC's inspection powers, search and entry powers and an enabling power to comment on investment practice.

\section{Principles for Issuers (Principle 16)}

187. The Bailiwick of Guernsey does not issue its own accounting or auditing standards; it follows internationally recognized accounting standards. The GFSC monitors the changing international standards and will continue to liaise with the local accounting profession, 
investment industry and other interested parties in respect of accounting and auditing matters that impact the Guernsey investment industry.

Principles for Market Intermediaries (Principle 24)

188. The GFSC intends to liaise with the finance sector with a view to promoting an Ordinance under the Protection of Investors (Bailiwick of Guernsey) Law, 1987 in 2004, which will include specific legislative provisions for dealing with the failure of a market intermediary.

Principles for Secondary Market (Principle 29)_Paragraph 110

189. The GFSC intends to publish a consultation document on the management of large exposures, default risk and market disruption and to issue new rules during 2004.

\section{Plan BY THE BAILIWICK OF GUERnSEY FOR AdDRESSING THE RECOMMENDED ACtion Plans of the International Monetary Fund to EnHance CoMPliance WITH INTERNATIONAL REGULATORY STANDARDS}

190. The Guernsey authorities (the States of Guernsey Advisory and Finance Committee, the Attorney General's Chambers, the Guernsey Financial Services Commission and the Financial Intelligence Service) value and attach great significance to the IMF's Module 2 assessment of the Bailiwick of Guernsey, which endorsed the Bailiwick's high level of compliance with international regulatory standards in banking, insurance, securities, anti-money laundering and combating the financing of terrorism, and best practice for company and trust service providers. The assessment was a welcome and positive experience.

191. The authorities also welcome the issues raised by the IMF, which will assist the Bailiwick to further enhance its implementation of established international standards.

192. Many of the IMF's recommendations are, or will be, satisfied by amendments to the framework already in progress at the time of the assessment.

193. The Bailiwick's standards were found by the IMF to be fully consistent with the Offshore Group of Banking Supervisors Statement of Best Practice for Trust and Company Service Providers. The authorities were, however, very concerned to be advised formally, soon after the review, that the IMF will not be assessing any other jurisdictions against the Statement. The authorities believe that the Statement represents an important international benchmark against which all jurisdictions which provide services to trusts and companies should be assessed. The absence of this benchmark means that the vast majority of jurisdictions which provide such services are not obliged to meet the standards in the Statement. This represents a missed opportunity for the IMF which could have made a substantial contribution to protecting the international financial system. 


\section{A. Authorities' Response to the IMF's Recommended Action Plans}

194. The format of this action plan is as follows:

- $\quad$ Response to the Recommended Action Plans to Improve Compliance with the Basel Core Principles.

- $\quad$ Response to the Recommended Action Plans to Improve Observance with the IAIS Core Principles.

- $\quad$ Response to the Recommended Action Plans to Improve Observance with the IOSCO Objectives and Principles of Securities Regulation.

- $\quad$ Response to the Recommended Action Plans to Improve Compliance with the FATF Recommendations.

195. The action plan covers recommendations made in the action plans in Volumes I and II of the IMF report.

\section{Recommendations Specific to the Banking Sector}

196. The authorities welcome the IMF's assessment and confirmation that the Bailiwick of Guernsey has achieved a high level of compliance with the Basel Committee Core Principles on Banking Supervision.

\begin{tabular}{lll}
\hline No. & Subject & Action Plan \\
\hline 1 & Objectives & Currently, the GFSC has a responsibility under the Financial Services \\
& Commission (Bailiwick of Guernsey) Law, 1987 to develop and effectively \\
& supervise finance business in Guernsey. The IMF's recommendation that the \\
& GFSC should be provided with a statutory obligation for the safety, soundness \\
and integrity of the financial system in place of its responsibility to develop the \\
finance sector has been noted. The States of Guernsey Advisory and Finance \\
Committee and the GFSC agree with the IMF's view that formalizing the \\
GFSC's approach in this manner better expresses the GFSC's current and \\
continuing objectives and will enhance the reputation and contribute to the \\
continuing development of the financial system in Guernsey. The Committee \\
proposes to seek amendment of the law at an early stage.
\end{tabular}


of regulatory bodies.

Staff resources of the GFSC have continued to grow in line with the size of the finance sector and the responsibilities of the GFSC. The IMF has recommended that the GFSC's Banking Division should carry out a "zero based" analysis of its staff needs based on the expected number of banks. This has been completed and, as a consequence, an additional analyst has been recruited since the assessment in order to assist the Division to carry out a systematic program of corporate governance and full scope safety and soundness on-site visits to banks.

\begin{tabular}{ll}
\hline Loan Evaluation \\
and Loan Loss
\end{tabular}$\quad \begin{aligned} & \text { Following the introduction of the Banking Supervision (Bailiwick of Guernsey) } \\
& \text { (Amendment) Law, 2003, it is a legal requirement for each Guernsey bank to } \\
& \text { Provisioning }\end{aligned} \quad \begin{aligned} & \text { review, at least annually their individual loans, asset classification and loss } \\
& \text { provisions (including on and off balance sheet exposures). Should the review } \\
& \text { identify any shortcomings, the bank is required to report any findings to the } \\
& \text { GFSC, together with details of how it proposes to address the shortcomings. }\end{aligned}$

With regard to policies followed by the GFSC, the scope of on-site credit assessments of banks was extended in early 2003 to give additional emphasis to credit quality and provisioning levels.

\begin{tabular}{lll}
\hline 4 & On-Site and Off- & The GFSC's Banking Division is planning full safety and soundness on-site \\
Site Supervision & visits for 2004. The visits will include techniques and practices to confirm or \\
(CP13 and 16) & $\begin{array}{l}\text { otherwise the existence and application of an effective and comprehensive risk } \\
\text { management process and control culture. Additional training of staff in this field } \\
\text { of work will continue. }\end{array}$
\end{tabular}

Meetings by the GFSC with external bank auditors will be more frequent and scope for increasing synergies will be explored.

\begin{tabular}{|c|c|c|}
\hline 5 & $\begin{array}{l}\text { Internal Control } \\
\text { and Audit } \\
(\mathrm{CP} 14)\end{array}$ & $\begin{array}{l}\text { Following the introduction of the Banking Supervision (Bailiwick of Guernsey) } \\
\text { (Amendment) Law, 2003, it is a legal requirement for each Guernsey bank to } \\
\text { review, at least annually the responsibilities and conduct of the bank's board of } \\
\text { directors with respect to corporate governance principles. Should the review } \\
\text { identify any shortcomings, the bank is required to report any findings to the } \\
\text { GFSC, together with the details of how it proposes to address the shortcomings. } \\
\text { GFSC guidance notes entitled "Guidelines for Corporate Governance and Risk } \\
\text { Management" are being revised in light of comments received during } \\
\text { consultation with banks and will be formally issued as soon as possible, } \\
\text { following consideration of the comments arising from the consultation. }\end{array}$ \\
\hline 6 & $\begin{array}{l}\text { Validation of } \\
\text { Supervisory } \\
\text { Information (CP19) }\end{array}$ & $\begin{array}{l}\text { Meetings will be held with the Guernsey Society of Chartered and Certified } \\
\text { Accountants to explore the possibility of the GFSC having access to working } \\
\text { papers in connection with the verification of quarterly returns and preparing } \\
\text { audited accounts. Where necessary the GFSC will also consider the benefits of } \\
\text { bilateral and trilateral meetings with auditors. }\end{array}$ \\
\hline 7 & $\begin{array}{l}\text { Cross Border } \\
\text { Banking } \\
(\mathrm{CP} 25)\end{array}$ & $\begin{array}{l}\text { With reference to the recommendation in Volume I that a formal confirmation } \\
\text { from home supervisors be obtained on an annual basis to complement the } \\
\text { confirmation of support that is obtained as part of the licensing process, the } \\
\text { GFSC is contacting all home supervisors. This process will continue on an } \\
\text { annual basis. }\end{array}$ \\
\hline
\end{tabular}




\section{Recommendations specific to the insurance sector}

197. The authorities welcome the IMF's assessment and confirmation that the Bailiwick of Guernsey has achieved a high level of compliance with the IAIS Core Principles.

\begin{tabular}{lll}
\hline No. Subject & \multicolumn{1}{c}{ Action plan } \\
\hline 1 & $\begin{array}{l}\text { Organization } \\
\text { (CP1) }\end{array}$ & $\begin{array}{l}\text { See the text under the headings "Objectives (CP 1.1)" and "Independence } \\
\text { (CP1.2)" in the recommendations specific to the banking sector of this action } \\
\text { plan for the response on the recommendations concerning the GFSC's } \\
\text { objectives and independence. }\end{array}$ \\
& $\begin{array}{l}\text { Since the IMF's assessment the staff of the Insurance Division has increased to } \\
\text { include an assistant actuary and two analysts, as recommended by the IMF. }\end{array}$ \\
\hline 2 & $\begin{array}{l}\text { Pith regard to solvency requirements, provisions exist within the Insurance } \\
\text { (CP8) }\end{array}$ & $\begin{array}{l}\text { Business (Bailiwick of Guernsey) Law, 2002 for the GFSC to modify the } \\
\text { solvency requirements of each insurer depending on the size, nature and } \\
\text { complexity of the risks being written. Solvency levels for individual insurers are } \\
\end{array}$ \\
& set on this basis. The GFSC's requirements can be imposed at the licensing \\
& stage as well as on an ongoing basis. In practice, this means that solvency \\
& requirements are much higher than the minimum legal levels set under the law. \\
& The solvency of individual insurers is continually monitored by the GFSC. \\
\hline 3 & $\begin{array}{l}\text { Administrative } \\
\text { fines } \\
\text { (CP14) }\end{array}$ & $\begin{array}{l}\text { Committee in } 2004 \text { on the recommendation concerning the imposition of } \\
\text { penalties. }\end{array}$ \\
\hline
\end{tabular}

\section{Recommendations specific to the securities sector}

198. The authorities welcome the IMF's assessment and confirmation that the Bailiwick of Guernsey has achieved a high level of compliance with the IOSCO Objectives and Principles of Securities Regulation.

\begin{tabular}{lll}
\hline No. & \multicolumn{1}{c}{ Subject } & \multicolumn{1}{c}{ Action plan } \\
\hline 1 & $\begin{array}{l}\text { Principles Relating } \\
\text { to the Regulator } \\
\text { (Principle 1) }\end{array}$ & $\begin{array}{l}\text { See the text under the heading "Objectives (CP 1.1)" in the recommendations } \\
\text { specific to the banking sector of this action plan for the response on the } \\
\text { recommendation concerning the GFSC's objectives. }\end{array}$ \\
& $\begin{array}{l}\text { The Control of Borrowing regime is being reviewed as part of a review of } \\
\text { company law and a consultation document will be issued in 2004. }\end{array}$ \\
\hline 2 & $\begin{array}{l}\text { Principles Relating } \\
\text { to the Regulator } \\
\text { (Principle 2) }\end{array}$ & $\begin{array}{l}\text { See the text under the heading "Independence (CP1.2)" in the } \\
\text { recommendations specific to the banking sector of this action plan for the } \\
\text { response on the recommendation concerning the GFSC's independence. }\end{array}$ \\
\hline $\begin{array}{l}\text { Principles for the } \\
\text { Enforcement of } \\
\text { Securities } \\
\text { Regulation } \\
\text { (Principle } 8)\end{array}$ & $\begin{array}{l}\text { The States Assembly approved the drafting of separate, explicit, statutory on- } \\
\text { site inspection powers with regard to investment licensees in 2002. }\end{array}$ \\
& $\begin{array}{l}\text { Consequently, the Financial Services Commission (Bailiwick of Guernsey) } \\
\text { (Amendment) Law, 2003 provides the States Assembly with an enabling power } \\
\text { to make an Ordinance covering this matter. It is intended that the States }\end{array}$ \\
& $\begin{array}{l}\text { Assembly will consider the Ordinance in early 2004. The Protection of } \\
\text { Investors (Bailiwick of Guernsey) Law, 1987 already provides the GFSC with } \\
\text { comprehensive powers to obtain information and interview investment } \\
\text { licensees' staff; on-site inspections have been conducted since 1989. }\end{array}$ \\
&
\end{tabular}


In addition, it is intended to promote an amendment to the Protection of Investors (Bailiwick of Guernsey) Law, 1987 which will provide the GFSC with powers of entry and search after obtaining a warrant from the Bailiff. A similar provision is already found in the other regulatory legislation administered by the GFSC.

With regard to the recommendation that the GFSC should possess a general power enabling it to comment on investment business management and market practice, the GFSC will report to the Advisory and Finance Committee on the recommendation in 2004.

\begin{tabular}{|c|c|c|}
\hline 4 & $\begin{array}{l}\text { Principles for } \\
\text { Issuers } \\
\text { (Principle 16) }\end{array}$ & $\begin{array}{l}\text { The Bailiwick of Guernsey does not issue its own accounting or auditing } \\
\text { standards; it follows internationally recognized accounting standards. The } \\
\text { GFSC monitors the changing international standards and will continue to liaise } \\
\text { with the local accounting profession, investment industry and other interested } \\
\text { parties in respect of accounting and auditing matters that affect the Guernsey } \\
\text { investment industry. }\end{array}$ \\
\hline 5 & $\begin{array}{l}\text { Principles for } \\
\text { Market } \\
\text { Intermediaries } \\
\text { (Principle 24) } \\
\end{array}$ & $\begin{array}{l}\text { The GFSC intends to liaise with the finance sector with a view to promoting an } \\
\text { Ordinance under the Protection of Investors (Bailiwick of Guernsey) Law, } 1987 \\
\text { in 2004, which will include specific legislative provisions for dealing with the } \\
\text { failure of a market intermediary. }\end{array}$ \\
\hline 6 & $\begin{array}{l}\text { Principles for } \\
\text { Secondary Market } \\
\text { (Principles } 28 \text { and } \\
\text { 29) }\end{array}$ & $\begin{array}{l}\text { The GFSC intends to publish a consultation document on the management of } \\
\text { large exposures, default risk, and market disruption and to issue new rules } \\
\text { during } 2004 \text {. }\end{array}$ \\
\hline
\end{tabular}

\section{Recommendations Specific to Anti-Money Laundering and Countering the Financing of Terrorism.}

199. The authorities welcome the IMF's assessment and confirmation that the Bailiwick of Guernsey has a sound legal and institutional AML/CFT framework with a high level of compliance with the Financial Action Task Force Recommendations on Money Laundering and the Special Recommendations on Terrorist Financing.

\begin{tabular}{|c|c|c|}
\hline No. & Subject & Action plan \\
\hline \multirow[t]{2}{*}{1} & $\begin{array}{l}\text { Ratification and } \\
\text { Implementation of } \\
\text { UN Instruments }\end{array}$ & $\begin{array}{l}\text { With the enactment of the Terrorism and Crime (Bailiwick of Guernsey) Law, } \\
2002 \text { all relevant legislation to satisfy the International Convention for the } \\
\text { Suppression of the Financing of Terrorism has been enacted. Application has } \\
\text { been made for the Convention to be extended to Guernsey. }\end{array}$ \\
\hline & $\begin{array}{l}\text { Criminalization of } \\
\text { ML and FT }\end{array}$ & $\begin{array}{l}\text { The Prevention of Corruption (Bailiwick of Guernsey) Law, 2003, which will } \\
\text { introduce a statutory offence of corruption, was approved by the States } \\
\text { Assembly in September 2003. Once it has received Royal Assent this law will } \\
\text { supersede the existing common law on corruption and assist the Bailiwick to } \\
\text { adopt the UN Convention Against Transnational Organized Crime (the Palermo } \\
\text { Convention). The authorities will maintain their program of legislation so that } \\
\text { the Convention can be extended to Guernsey. }\end{array}$ \\
\hline 2 & $\begin{array}{l}\text { Confiscation of } \\
\text { Proceeds of Crime }\end{array}$ & $\begin{array}{l}\text { Consideration will be given to amending the Terrorism and Crime (Bailiwick of } \\
\text { Guernsey) Law, } 2002 \text { to provide for the appointment of a receiver for all }\end{array}$ \\
\hline
\end{tabular}


or Property used to Finance Terrorism property owned by a defendant and for the sale of such property to satisfy a confiscation order.

During 2004, consideration will be given to new legislation based on the UK Proceeds of Crime Act in respect of the introduction of a statutory asset forfeiture fund and legislation for asset sharing with other jurisdictions.

Increased
Diligence of FIs

The FIU and Processes for Receiving, Analyzing, and Disseminating Financial Information for the Criminal Justice (Miscellaneous Provisions) (Bailiwick of Guernsey) Law in 2002. This law is intended to be presented to the States Assembly for financial services business fails to report a suspicious transaction - this will replace the existing legal provision whereby the reporting of a suspicion is a also include provisions which permit the Financial Intelligence Service to prescribe the format of suspicious transaction reports.
The States Assembly approved a policy letter incorporating drafting instructions approval early in 2004 and it will include provisions making it an offence if a defense against committing the crime of money laundering. The new law will

During 2004, consideration will be given to a requirement for information to be provided by reporting entities on an intelligence basis to the Financial Intelligence Service as part of the drafting of the Guernsey equivalent of the UK Proceeds of Crime Act.

The Criminal Justice (Proceeds of Crime) (Bailiwick of Guernsey) Regulations, 2002 provide that a court may take account of the Guidance Notes on the Prevention of Money Laundering and Countering the Financing of Terrorism and any other guidance issued, adopted or approved by the GFSC. It is proposed to amend the Regulations to state explicitly that the GFSC must issue guidance notes under the Regulations.

Training of two investigators for the Financial Intelligence Service has been approved. In addition, an intelligence analyst and an administrative assistant were appointed earlier in 2003.

\begin{tabular}{|c|c|c|}
\hline 4 & $\begin{array}{l}\text { Law Enforcement } \\
\text { and Prosecution } \\
\text { Authorities, } \\
\text { Powers and Duties }\end{array}$ & $\begin{array}{l}\text { The Regulation of Investigatory Powers (Bailiwick of Guernsey) Law, 2003, } \\
\text { which was approved by the States Assembly in September 2003, contains } \\
\text { provisions that regulate the component parts of controlled delivery. This law } \\
\text { includes the legal authority required in order to conduct directed and intrusive } \\
\text { surveillance, property interference and the use of covert human intelligence } \\
\text { sources. }\end{array}$ \\
\hline & & $\begin{array}{l}\text { The Financial Intelligence Service has given consideration to the development } \\
\text { of its information technology resources and tenders have been issued. Work on } \\
\text { the new computer system will commence as soon as possible. }\end{array}$ \\
\hline 5 & $\begin{array}{l}\text { General } \\
\text { Framework }\end{array}$ & $\begin{array}{l}\text { Consideration will be given to the extension of the application of the AML/CFT } \\
\text { framework to MSBs (bureau de change activities, cheque cashing and money } \\
\text { transmission services) as part of the current consideration of the introduction of } \\
\text { new Regulations and Guidance Notes. }\end{array}$ \\
\hline 6 & $\begin{array}{l}\text { Customer } \\
\text { Identification }\end{array}$ & $\begin{array}{l}\text { The Criminal Justice (Proceeds of Crime) (Bailiwick of Guernsey) Regulations, } \\
2002 \text { already contain detailed customer identification requirements which must } \\
\text { be followed by financial services businesses. Failure to comply with the } \\
\text { Regulations is an offence. The IMF's comments about the documentary } \\
\text { requirements for legal entities will be considered as part of the changes to the } \\
\text { Regulations and the Guidance Notes arising from the Financial Action Task }\end{array}$ \\
\hline
\end{tabular}


Force's new Recommendations (issued in June 2003).

With regard to the other comments made by the IMF, the GFSC has issued draft revised Guidance Notes for consultation.

The GFSC routinely communicates its policies to the finance sector and is consulting with the finance sector in connection with the publication of a statement on the FATF's June 2003 Recommendation on introduced business.

7 Wire Transfers The GFSC has issued draft revised Guidance Notes on the Prevention of Money
Laundering and Countering the Financing of Terrorism for consultation, which

Ongoing

Monitoring of address the enhancements to the framework on ongoing monitoring of accounts

Accounts and and transactions recommended by the IMF.

Transactions

8 Record Keeping The GFSC has issued draft revised Guidance Notes on the Prevention of Money Laundering and Countering the Financing of Terrorism for consultation which include the specific recommendations on record keeping made by the IMF.

9 Suspicious See the text under "Recommendations Specific to Anti-Money Laundering and Transactions Countering the Financing of Terrorism", point 3, paragraph 1, for the response Reporting to the recommendation to introduce a new offence for failure to report a suspicious transaction.

Consideration will be given to providing the Financial Intelligence Service with the authority to give instructions to reporting entities and to require financial services businesses to observe instructions of the Financial Intelligence Service as part of the drafting of the Guernsey equivalent of the UK Proceeds of Crime Act.

The GFSC has issued draft revised Guidance Notes on the Prevention of Money Laundering and Countering the Financing of Terrorism for consultation, which address the issue of the use of the term "key staff".

\begin{tabular}{|c|c|c|}
\hline 10 & $\begin{array}{l}\text { Measures to Cope } \\
\text { with Countries } \\
\text { with Insufficient } \\
\text { AML Measures } \\
\text { Internal Controls, } \\
\text { Compliance and } \\
\text { Audit }\end{array}$ & $\begin{array}{l}\text { Amendments to the Criminal Justice (Proceeds of Crime) (Bailiwick of } \\
\text { Guernsey) Regulations, } 2002 \text { and the Guidance Notes on the Prevention of } \\
\text { Money Laundering and Countering the Financing of Terrorism have been issued } \\
\text { for consultation, which will require all financial services businesses to put in } \\
\text { place adequate screening procedures to ensure high standards when hiring } \\
\text { employees. They also include additional detail on the application of AML/CFT } \\
\text { standards to the branches and subsidiaries of Guernsey financial services } \\
\text { businesses. }\end{array}$ \\
\hline
\end{tabular}

With regard to the requirements for financial services businesses to appoint a person to receive suspicious transaction reports and to require financial services businesses to notify the GFSC of any change in such position, amendments to the Criminal Justice (Proceeds of Crime) (Bailiwick of Guernsey) Regulations, 2002 have been issued for consultation, which require the designation of a reporting officer who should be resident in the Bailiwick of Guernsey and whose name and title must be provided to the GFSC.

11 Enforcement It is intended that legislation will be promoted in 2004 to provide the GFSC Powers and with the power to issue a written directive or order in respect of persons Sanctions undertaking investment business. A similar power is already contained in the other regulatory legislation administered by the GFSC. 
Guernsey) Law, 1987 will be promoted in 2004, which will provide for the appointment by the GFSC of inspectors to investigate investment licensees. A similar power is already contained in the other regulatory legislation administered by the GFSC.

The GFSC will report to the Advisory and Finance Committee during 2004 in respect of civil money penalties and administrative fines.

An enabling provision has been included in the Financial Services Commission (Bailiwick of Guernsey) (Amendment) Law, 2003, which permits the States Assembly to introduce by Ordinance separate, explicit, legal provisions for onsite visits to be undertaken by the GFSC. An Ordinance is intended to be laid before the States Assembly for approval early in 2004.

$12 \quad$ Banking and The GFSC has issued draft revised Guidance Notes on the Prevention of Money

Securities SectorLaundering and Countering the Financing of Terrorism for consultation which Specific Criteria include the recommendations on on-going monitoring of accounts and transactions. See the text under point 11 , paragraph 4 , for the response to the recommendation on enforcement powers and sanctions made by the IMF. 
